Check for updates

Cite this: RSC Adv., 2019, 9, 40588

Received 9th October 2019

Accepted 10th November 2019

DOI: 10.1039/c9ra08211e

rsc.li/rsc-advances

\section{Photoresponsive behavior of hydrophilic/ hydrophobic-based novel azobenzene mesogens: synthesis, characterization and their application in optical storage devices $\uparrow$}

\begin{abstract}
Sunil B. N., ${ }^{\text {ab }}$ Wan Sinn Yam ${ }^{\star c}$ and Gurumurthy Hegde (D) *a
Three series of alkoxy chain-bearing azobenzene-derived quaternary ammonium iodides with an alkoxy chain at one end, namely $N, N$-diethanol-6-(4-((4'-alkyloxyphenyl)diazenyl)phenoxy)hexan-1-ammonium iodides, $N$-ethyl- $N$-ethanol-6-(4-((4'-alkyloxyphenyl)diazenyl)phenoxy)hexan-1-ammonium iodides and N,N-diethyl-6-(4-((4'-alkyloxyphenyl)diazenyl)phenoxy)hexan-1-ammonium iodides were synthesized and characterized. Their mesomorphic and photoswitching properties were examined via polarising optical microscopy (POM), differential scanning calorimetry (DSC) and UV-vis spectrophotometry. The liquid crystalline tilted schlieren texture of smectic $C$, non-tilted natural focal conic texture of smectic $A$ and smectic B phases were observed in the $N, N$-diethanol- and $N$-ethyl- $N$-ethanol-bearing ammonium group substituted at the terminal via the alkoxy chain of the azo moiety. In these azo moieties, the equilibrium time for trans-cis isomerization was about $1 \mathrm{~min}$ and cis-trans isomerization occurred at around 590 min, which had the highest alkoxy chain and no hydroxyl group on their head group. The absence of a hydroxyl group on the terminal head group resulted in slow thermal back relaxation, whereas the hydroxyl group-bearing head group showed fast thermal back relaxation. These results suggest that the influence of the substituent on the cationic ammonium head group and alkoxy chain length on the photoisomerization of the azo compounds is vital for optical storage devices. Furthermore, the device fabricated using these materials demonstrated that they are excellent candidates for optical image storage applications.
\end{abstract}

\section{Introduction}

Optical storage devices have attracted increasing attention in the field of information technology over the last few years. ${ }^{\mathbf{1 - 5}}$ Organic photochromic compounds are used to evaluate the photoinduced behaviour of optical storage devices. ${ }^{6,7}$ This process arises from the reversible photoinduced isomerization of a photochromic group such as azobenzene. The azobenzene chromophore is a good candidate for storing data optically due to its photosensitivity and good photoisomerization properties. ${ }^{8-11}$ Upon UV illumination $\left(\sim 365 \mathrm{~nm}\right.$ related to the $\pi-\pi^{*}$ transition), its thermodynamically more stable rod-like molecular form of $E$ or trans isomer is converted into the bent $Z$ or cis isomer. Reverse cis-trans isomerization can be achieved via illumination under visible light $(\sim 400-500 \mathrm{~nm}$, related to the $\mathrm{n}-$

${ }^{a}$ Centre for Nano-materials and Displays, B.M.S. College of Engineering, Bull Temple Road, Bengaluru 560019, India. E-mail: murthyhegde@gmail.com

${ }^{b}$ Department of Chemistry, B.M.S. College of Engineering, Bangalore, India 560019 ${ }^{c}$ School of Chemical Sciences, Universiti Sains Malaysia, 11800 USM Penang, Malaysia.E-mail: wansinn@usm,my

$\dagger$ Electronic supplementary information (ESI) available. See DOI: 10.1039/c9ra08211e $\pi^{*}$ transition). This reverse transformation can also occur in the "dark" via a process known as thermal back relaxation. ${ }^{12,13}$ The decoration of different functional groups on the azobenzene chromophore has been studied to enhance its optical storage properties. $^{\text {14-21 }}$

Ionic liquids have been developed in the past two decades because of their unique physicochemical properties and highly tunable features with chemical modification. ${ }^{22-25}$ Thus, it is possible to design functionalized azobenzene-based ionic liquids by introducing quaternary ammonium salts into the photoresponsive unit of azobenzene. ${ }^{26,27}$ In this context, some azobenzene-based ionic liquids have been designed and used in many applications such as catalysis ${ }^{28}$ sensors, ${ }^{29}$ drug delivery ${ }^{30}$ and coatings. $^{31}$ Based on a recent literature survey, ${ }^{32-34}$ azobenzene-based ionic liquids are rarely used in the field of optical storage devices. In recent years, ${ }^{35-37}$ some photoresponsive ionic liquids have been reported. The azobenzenebased ionic liquid 4-butylazobenzene-40-hexyloxytrimethylammonium trifluoro-acetate $\left(\left[\mathrm{C}_{4} \mathrm{AzoC}_{6} \mathrm{TMA}\right]\right.$ [TfO]) with an azobenzene unit bridged between the alkyl chain has been synthesized and its reversible micelle-vesicle transformation under UV-vis illumination studied. ${ }^{38}$ Similarly, the synthesis 
and reversible transformation of the photoresponsive ionic liquid 1-(4-methyl azobenzene)-3-tetradecylimidazolium bromide $\left(\left[\mathrm{C}_{14} \mathrm{mimAzo}\right] \mathrm{Br}\right)$ with an azobenzene group were investigated. ${ }^{39}$ However, to understand the photoresponsive behavior of azobenzene-based ionic liquids, a detailed investigation of this class of azobenzenes with quaternary ammonium salts in other positions of the different functional groups is necessary.

In this work, we designed, synthesized and characterized 3 types of photoresponsive compounds, N,N-diethanol-6-(4-( ( $4^{\prime}-$ alkyloxyphenyl)diazenyl)phenoxy)hexan-1-ammonium iodides (hereafter named as compounds 22-24), $\mathrm{N}$-ethyl- $\mathrm{N}$-ethanol-6-(4((4'-alkyloxyphenyl)diazenyl)phenoxy)hexan-1-ammonium iodides (hereafter named as compounds 25-27) and $N, N$ diethyl-6-(4-((4'-alkyloxyphenyl)diazenyl)phenoxy)hexan-1ammonium iodides (hereafter named as compounds 28-30). In the ammonium salts of these ionic liquids, the alkoxy chain is at one end of the azobenzene group (i.e. the azobenzene and head group are bridged by the alkoxy chain, as shown in Fig. 1) and other end has different alkoxy chain lengths. The mesomorphic and photoisomerization behavior modulation of these ionic liquids in solution and in solid through UV light irradiation were investigated via UV-vis spectroscopy. The parameters of the liquid crystalline phase, phase transition temperature, photoisomerization efficiency and thermal back relaxation were determined.

This study provides useful information for creating optical storage devices by understanding the structure-property relationship of azobenzene-based ionic liquids. The photoisomerization and liquid crystalline properties of the intermediates were also studied for a better understanding between them.

\section{Results and discussion}

\subsection{Synthesis}

The new azobenzene-based ammonium salts discussed herein were prepared following the procedure in Scheme 1.

4-Acetamidophenol was $O$-alkylated using 1-bromoalkanes to produce 4-acetamidophenoxyalkanes (1-3) and further refluxed with alcoholic sodium hydroxide to give 4-alkyloxyanilines (4-6). The 4-alkyloxyanilines were diazotized with sodium nitrite and conc. $\mathrm{HCl}$ at $0{ }^{\circ} \mathrm{C}$ and the diazonium solution was treated with phenol in the presence of sodium carbonate to obtain the coupled products 7-9. Compounds 7-9

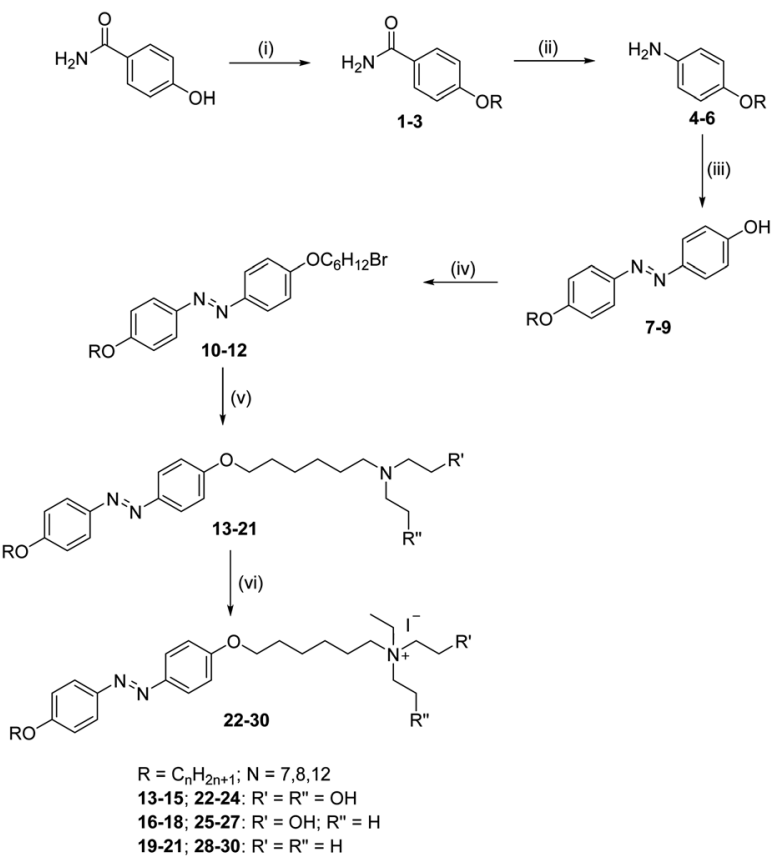

Scheme 1 Reagents and conditions: (i) 1-bromoalkanes (1.1 equiv.), ( $n$ $=7,8,12), \mathrm{K}_{2} \mathrm{CO}_{3}$ (3.0 equiv.), refluxing in acetone, $48 \mathrm{~h}$. (ii) Refluxing in $\mathrm{NaOH} / \mathrm{EtOH}$, overnight. (iii) Cooled in $\mathrm{HCl}_{\text {conc }}$ (aq); cooled $\mathrm{NaNO}_{2}$ (aq), stirred for $1 \mathrm{~h}$; cooled phenol/EtOH and $\mathrm{Na}_{2} \mathrm{CO}_{3}$ (aq), stirred at $0{ }^{\circ} \mathrm{C}$ for $1 \mathrm{~h}$. (iv) 1,6-Dibromohexane, (7.0 equiv.), $\mathrm{K}_{2} \mathrm{CO}_{3}$ (3.0 equiv.), refluxing in acetone, $7 \mathrm{~h}$. (v) Substituted amines (in excess), refluxing in 2-propanol, $38 \mathrm{~h}$. (vi) Ethyl iodide (in excess.), refluxing in acetonitrile, $36 \mathrm{~h}$.

were treated with 1,6-dibromohexane, and refluxed overnight under a nitrogen atmosphere to obtain compounds 10-12, and then reacted with substituted amines to produce 13-21. Compounds 22-30 were obtained upon treatment with ethyl iodide. The crude product was recrystalized from a mixture of ethanol $/ n$-hexane and characterized using ${ }^{1} \mathrm{H}$-NMR, ${ }^{13} \mathrm{C}-\mathrm{NMR}$, HRMS and elemental analyses.

\subsection{Azobenzene mesogen bearing terminal bromo group via alkoxy chain}

The bromo group was substituted at the terminal end (via the alkoxy chain) of azobenzene derivatives 7-8 bearing different alkoxy chain lengths on the other end of the phenyl ring. The bromo group was fixed at one end and the alkoxy chain varied at the other end of compounds 10-12. The push-pull type effect

where, $\mathrm{n}=7,8,12$

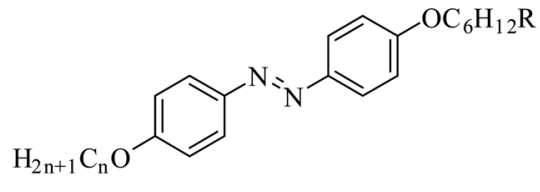

$\mathrm{R}=$ Bromo, te rtiary a mine, quarta nary a mmonium sa lt

$\mathrm{Br}$

$$
\begin{array}{ll}
\mathrm{N}\left(\mathrm{C}_{2} \mathrm{H}_{5}\right)_{2} & { }^{+} \mathrm{N}\left(\mathrm{C}_{2} \mathrm{H}_{5}\right)_{2} \mathrm{I}^{-} \\
\mathrm{N}\left(\mathrm{C}_{2} \mathrm{H}_{5}\right) \mathrm{C}_{2} \mathrm{H}_{4} \mathrm{OH} & { }^{+} \mathrm{N}\left(\mathrm{C}_{2} \mathrm{H}_{5}\right) \mathrm{C}_{2} \mathrm{H}_{4} \mathrm{OHI}^{-} \\
\mathrm{N}\left(\mathrm{C}_{2} \mathrm{H}_{4} \mathrm{OH}\right)_{2} & { }^{+} \mathrm{N}\left(\mathrm{C}_{2} \mathrm{H}_{4} \mathrm{OH}\right)_{2} \mathrm{I}^{-}
\end{array}
$$

Fig. 1 Chemical structures of the azobenzene-based ionic and non-ionic liquids under investigation. 
was observed in these types of molecules due to the presence of the bromo group, which acts as an electron withdrawing group, whereas, the alkoxy chain acts as an electron donating group. The influence of the alkoxy chain and bromo group on the mesomorphic and photoswitching properties of the azobenzene chromophore were studied in detail.

2.2.1 Mesomorphic studies. Mesomorphic studies on 1012 were performed using polarizing optical microscopy (POM) in the crystalline phase upon heating at the rate of $2{ }^{\circ} \mathrm{C}$ per min. The azobenzene-based mesogen formed different types of enantiotropic mesophases with phase sequences depending on the alkoxy chain length (see Table 1). Compounds $\mathbf{1 0}$ and $\mathbf{1 2}$ exhibited a non-tilted smectic (SmA) phase, while compound 11 formed tilted an SmC phase along with an SmA phase.

Fig. 2 shows the natural focal conic texture, which is typical of the SmA phase, exhibited by compounds 10-12 at the respective temperatures. The phase transition temperature and enthalpy changes were determined via differential scanning calorimetry (DSC) upon heating at $5{ }^{\circ} \mathrm{C} \mathrm{min}^{-1}$. A summary of the phase transition temperatures, mesophase types and transition enthalpies is given in Table 1. The DSC thermograms are presented in the ESI. $\dagger$

2.2.2 Photoswitching properties. The photoswitching studies on intermediates 10-12 were performed using a UV-vis spectrophotometer with a quartz cuvette and chloroform as the solvent. Before UV illumination, compounds 10-12 showed a strong absorption peak at the wavelength of $359-360 \mathrm{~nm}$ and weak band at $\sim 450 \mathrm{~nm}$, which correspond to the symmetry allowed $\pi-\pi^{*}$ transition and symmetry forbidden $n-\pi^{*}$ transition, respectively. There was no notable difference among the absorption spectra of compounds 10-12 due to their similar chemical architecture. Therefore, an increase in the length of the alkoxy chain does not affect the wavelength of the absorption spectrum.

During UV illumination, the typical maximum absorption wavelength at $359 \mathrm{~nm}$ disappeared, while a peak appeared at $\sim 450 \mathrm{~nm}$ due to an increase in the content of cis isomer. The isomerisation process of $\mathbf{1 0}$ was recorded as a function of UV irradiation time. Compounds 10-12 took around $44 \mathrm{~s}$ to reach the photoequilibrium state and upon further continuous irradiation of UV light up to $60 \mathrm{~s}$, there were no changes in their absorption spectra. This suggests the trans isomer reached its equilibrium state of isomerization reaction. After reaching the photostationary state, the thermal back relaxation of the cis-trans isomerization was examined by keeping the samples in the dark. Among them, compound $\mathbf{1 1}$ showed a good thermal back relaxation time of about $590 \mathrm{~min}$, whereas, 10 showed a fast back relaxation time of $\sim 100 \mathrm{~min}$. The normalized absorption spectra upon UV illumination and thermal back relaxation of 10-12 are shown in Fig. 3 and 4, respectively. The peak absorbance graph was plotted as a function of time by extracting data from the absorption spectra of compounds 10-12. Graphs (a and b) (in

Table 1 Phase transition temperatures, mesophase types, and transition enthalpies $\left[\Delta H / \mathrm{kJ} \mathrm{mol}^{-1}\right]$ of compounds 10-12 upon heating ${ }^{a}$<smiles>BrCCCCCCOC1=CCC(N=Nc2ccc(OCCCCCCBr)cc2)C=C1</smiles>

\begin{tabular}{lll} 
Compound code & $n$ & Phase transitions $T /{ }^{\circ} \mathrm{C}\left[\Delta H / \mathrm{kJ} \mathrm{mol}^{-1}\right]$ \\
\hline $\mathbf{1 0}$ & 7 & H: Cr 103.80 [54.46] SmA 111.77 [0.92] Iso \\
$\mathbf{1 1}$ & 7 & H: Cr 95.69 [50.96] SmC 109.67 (1.90) SmA 113.54 [1.14] Iso \\
$\mathbf{1 2}$ & 12 & H: Cr 100.03 [77.0] SmA 112.29 (9.73) Iso
\end{tabular}

${ }^{a}$ Transition temperatures and enthalpy values were taken from the DSC heating $(\mathrm{H})$ scans at $5{ }^{\circ} \mathrm{C} \mathrm{min}^{-1}$; abbreviations: $\mathrm{Cr}=\mathrm{crystalline}$ solid; $\mathrm{SmA}$ $=$ smectic phase A phase; $\mathrm{SmB}=$ smectic $\mathrm{B}$ phase; $\mathrm{SmC}=$ smectic $\mathrm{C}$ phase; and Iso = isotropic liquid.
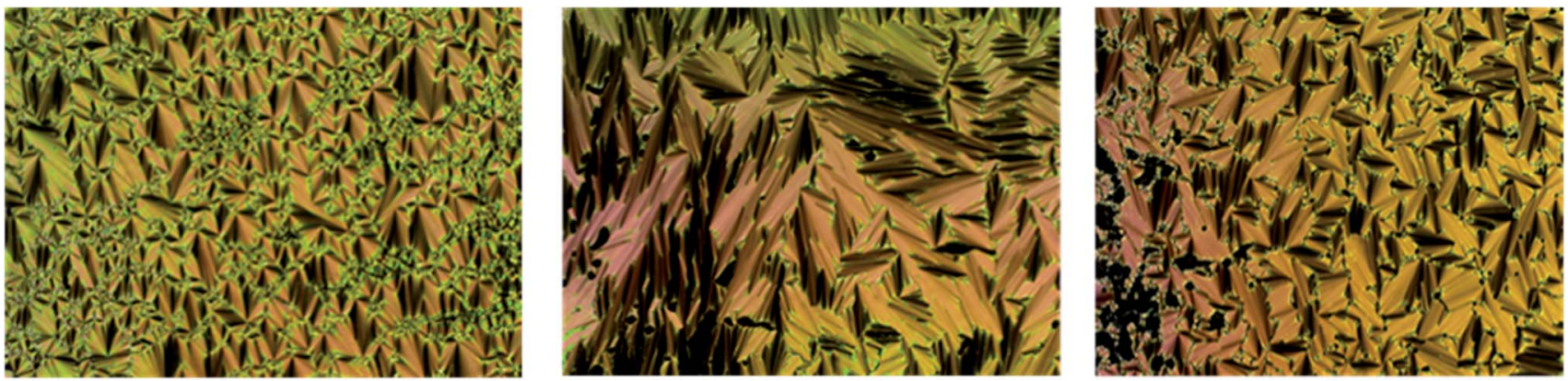

Fig. 2 The SmA phase exhibiting the natural focal conic texture as seen in compound 10, 11 and 12 at respective temperatures. Magnification used is $10 x$. 

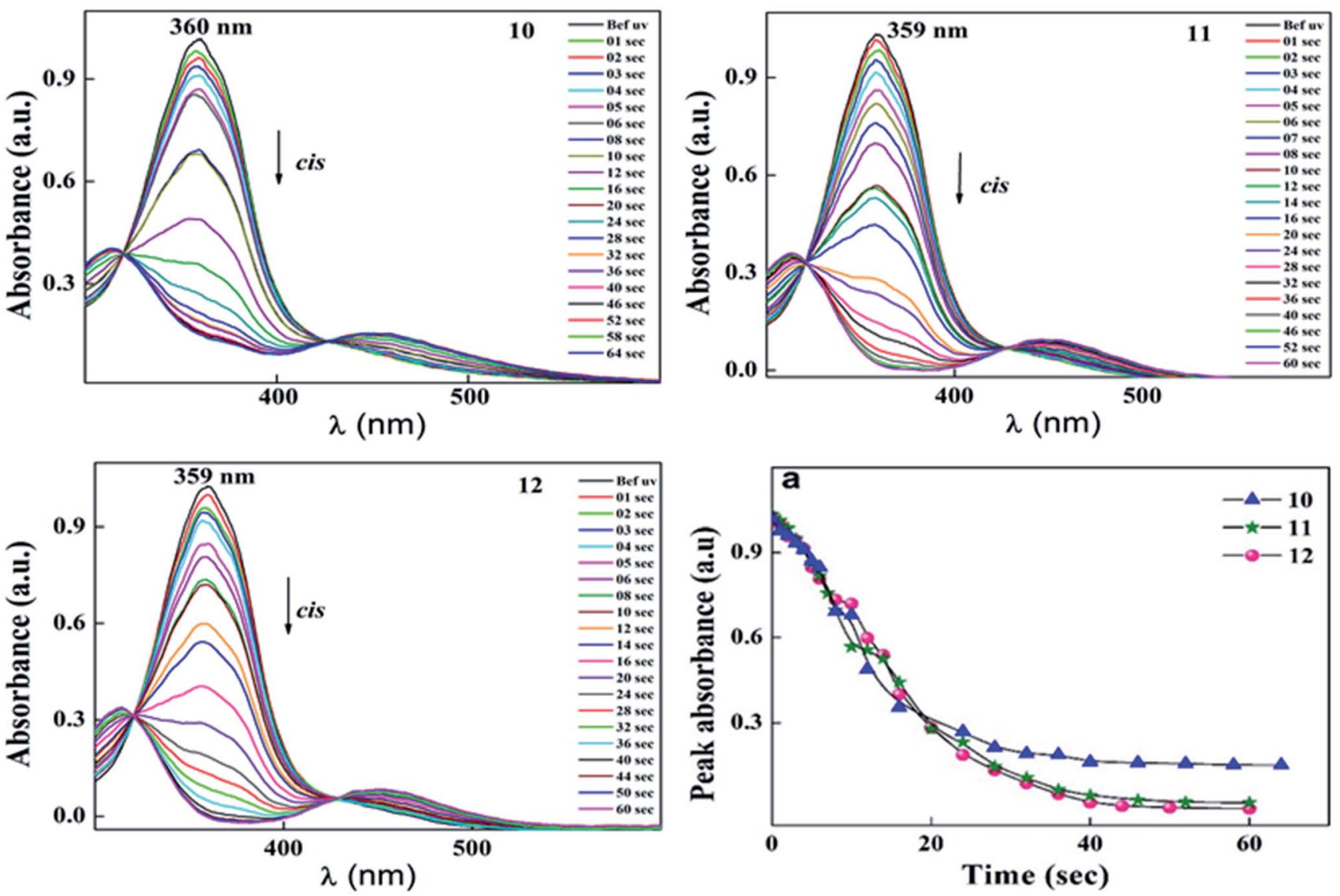

Fig. 3 Normalized absorption spectra of compounds 10-12 as a function of UV irradiation time and graph (a) represents a peak absorbance plot for trans-cis isomerization, extracted from the absorption spectra (in this figure) of 10-12. Intensity of the UV illumination was $1 \mathrm{~mW}^{\mathrm{cm}}{ }^{-2}$.

Fig. 3 and 4, respectively) show the peak absorbance graph of UV illumination and thermal back relaxation of compounds 10-12 with respect to irradiation time and recovery time, respectively.

For trans-cis isomerization of 10-12, the equilibrium state of the $E / Z$ isomer ratio was dependent on the wavelength. After exposure to a wavelength of $365 \mathrm{~nm}$, conversion efficiency of the trans isomer was around $90 \%$. Considering the case of sample 12, the conversion efficiency of trans-cis isomerization was 99\%, whereas, 10 showed 85\%. After $40 \mathrm{~s}$ UV irradiation, the conversion efficiency of these compounds remained the same. The photoconversion efficiency of the trans-cis isomerisation was determined using eqn (1). ${ }^{\mathbf{4 0}}$

$$
\mathrm{CE}=\frac{A_{\left(t_{0}\right)}-A_{\left(t_{\infty}\right)}}{A_{\left(t_{0}\right)}}
$$

where CE is the conversion efficiency, and $A_{\left(t_{0}\right)}$ and $A_{\left(t_{\infty}\right)}$ are absorbance before and after UV illumination, respectively. A summary of the trans-cis isomerization time, thermal back relaxation of cis-trans isomerization and photoconversion efficiency data is shown in Table 2 .

\subsection{Azobenzene-mesogen bearing a terminal tertiary amine group}

The bromo group was replaced by $N, N$-diethanol, $N$-ethyl- $N$ ethanol, and $N, N$-diethyl containing an amine group at the terminal with the same alkoxy chain length of intermediates 1012 at one end, and the other end of the azo ring bearing different alkoxy chain lengths. The mesomorphic and photoswitching properties of intermediates 13-21 were investigated here. These types of compounds exhibited a push-push type effect due to the electron donating nature of both groups present in the side chain. The influence of the hydrophobic and hydrophilic nature of the substituted tertiary amine on the mesomorphism and photoisomerization properties were extensively studied.

2.3.1 Mesomorphic studies. The liquid crystalline properties of intermediates 13-21 were examined similarly to 10-12 using POM and DSC. Three types of enantiotropic phases were observed in the $\mathrm{N}, \mathrm{N}$-diethanol, $\mathrm{N}$-ethyl- $\mathrm{N}$-ethanol, and $\mathrm{N}, \mathrm{N}$ diethyl substituted amine compounds. The $N, N$-diethanol substituted amine 15 exhibited schlieren texture of smectic $\mathrm{C}$ and smectic B phases, whereas, in the case of the $N$-ethyl- $N$ ethanol amine-bearing compound 18, it showed smectic $\mathrm{C}$ and smectic A phases upon heating. The polarizing optical images are shown in Fig. 5 together with the representative mesophase of $\mathrm{SmC}$ and $\mathrm{SmB}$ for compounds $\mathbf{1 8}$ and $\mathbf{1 5}$ at the respective temperature. However, the compounds possessing the highest alkoxy chain $(n=12)$ showed mesophases, whereas, the other two lower alkoxy homologues ( $n=7$ and 8 ) were non-mesogenic in nature. The $\mathrm{N}, \mathrm{N}$-diethyl amine group-containing compounds 

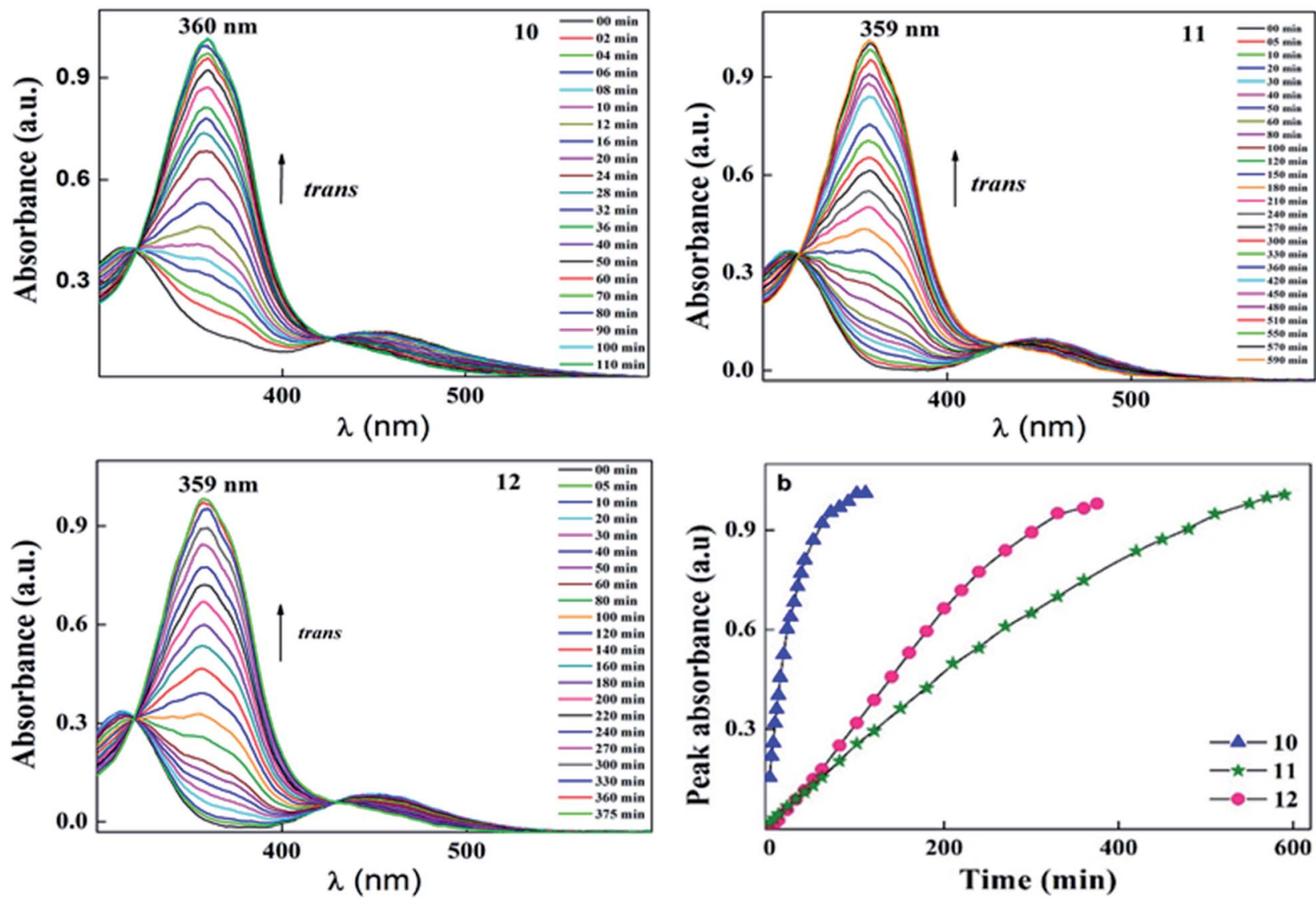

Fig. 4 Normalized absorption spectra of compounds 10-12 as a function of recovery time during thermal back relaxation and graph (b) represents the peak absorbance plot for cis-trans isomerization, which was extracted from the absorption spectra (Fig. 4) of 10-12.

Table 2 A summary of the $E / Z$ isomerisation, thermal back relaxation and its photoconversion efficiency (CE \%) data

\begin{tabular}{llll}
\hline & $\begin{array}{l}\text { trans-cis } \\
\text { Compound code }\end{array}$ & isomerization in s & Thermal back relaxation \\
in min & CE \% \\
\hline $\mathbf{1 0}$ & 44 & 100 & 85.67 \\
$\mathbf{1 2}$ & 44 & 590 & 98.25 \\
& 44 & 375 & 99.20
\end{tabular}

19, 20 and 21 also did not show liquid crystalline phases due to the hydrophobic nature of the substituted group on the tertiary amine. This information is vital to achieve mesomorphicity when tuning the alkoxy homologues.

A summary of the phase transition temperature and transition enthalpies are given in Table 3. The DSC thermograms for all the compounds are given in the ESI. $\dagger$

2.3.2 Photoswitching properties. The UV-vis investigation showed the influence of $N, N$-diethanol, $N$-ethyl- $N$-ethanol, $N, N$ diethyl containing an amine group on the isomerisation of intermediates 13-21. The photoisomerization of 13-21 was examined similarly to 10-12. The normalized absorption spectra upon UV illumination and thermal back relaxation of intermediates 13-21 are shown in Fig. 6 and Fig. 7, respectively. The peak absorbance graph was plotted similarly to 10-12, and
Fig. 8 shows the peak absorbance plots upon UV illumination (graph (c)) and thermal back relaxation (graph (d)) with respect to time. As Fig. 8 suggests, reversible isomerization depends on the alkoxy chain and substituted groups the on nitrogen atom of the amine group. The thermal back relaxation time increased as the length of the alkoxy chain increased. The presence of a hydroxyl group on amine resulted in fast-thermal back relaxation, whereas, it was slow in the case of the alkyl chain substituted amine. For example, the $N, N$-diethanol aminebased azobenzene with a terminal alkoxy chain length of $n=$ 8 reached photosaturation at a time of $\sim 80 \mathrm{~s}$, whereas, its thermal back relaxation was about $240 \mathrm{~min}$. A summary of the $E / Z$ isomerisation, thermal back relaxation time and its photoconversion efficiency of intermediates $\mathbf{1 3 - 2 1}$ are given in Table 4.

The photoconversion efficiency of $E / Z$ isomerisation was determined using eqn (1). The photoconversion efficiency of intermediates 13-21 was more than $90 \%$, indicating that the thermally stable trans isomer was converted to the unstable cis isomer to a great extent. In the case of compounds 13-18, conversion of the trans isomer to the cis isomer took more time compared to that for 19-21 due to the presence of a hydroxyl group on the amine group. The intermolecular hydrogen bonding effect of the hydroxyl group increased the equilibrium time for the isomerization reaction. 

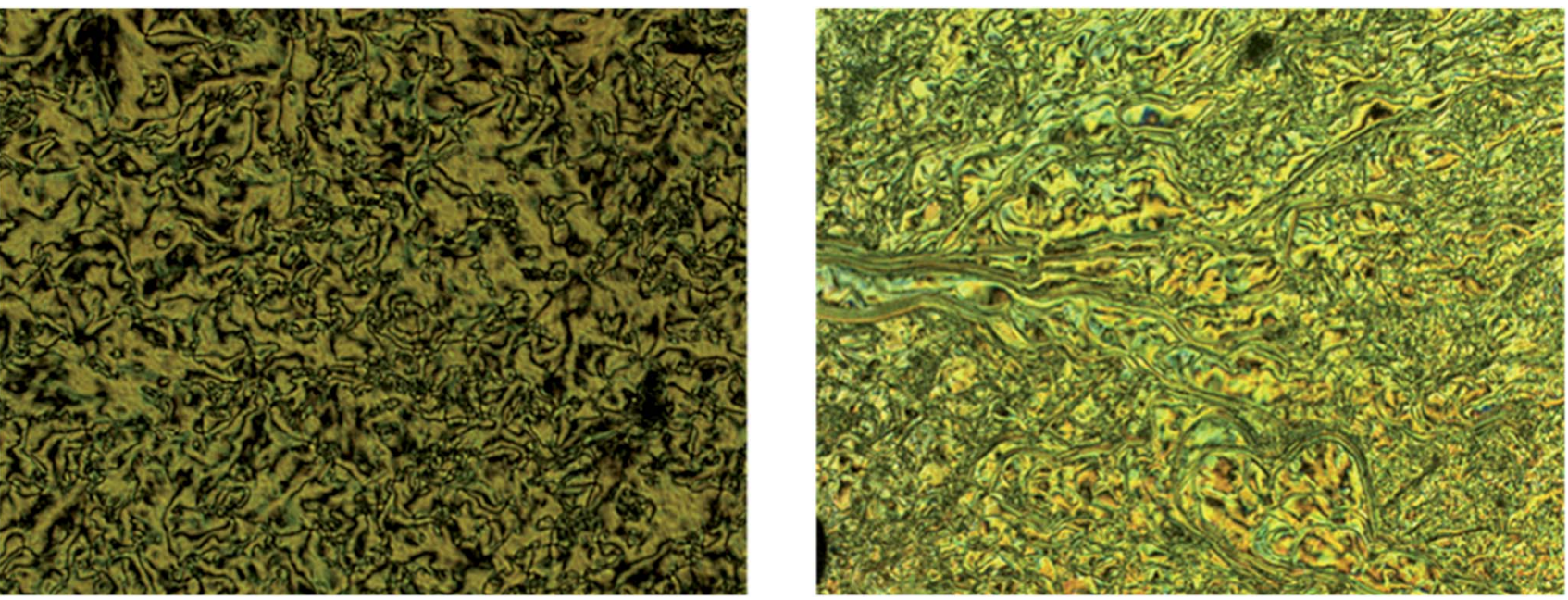

Fig. 5 Schlieren texture of SmC phase observed in compound 18 (left) and SmB phase for compound 15 (right) magnification $10 \times$.

\subsection{Azobenzene mesogen bearing a terminal quaternary ammonium group}

Azobenzene is the most efficient and extensively studied chromophore, where azobenzene derivatives with the trans isomer are thermodynamically more stable than that with the cis isomer. In this section, we present the mesomorphic and photoswitching properties of the quaternary ammonium salt bearing alkoxy azobenzene. Generally quaternary ammonium salts are called cationic surfactants, which are prepared by adding an ethyl group to the nitrogen atom of a tertiary amine. Similarly, the quaternary ammonium group-based azobenzene derivatives were prepared by adding an ethyl group to the terminal tertiary amine of intermediates 13-21. The mesomorphic properties and photo-induced isomerization of the azobenzene-based mesogen-bearing cationic surfactants (2230) were examined in detail.
2.4.1 Mesomorphic studies. The liquid crystalline properties of compounds 22-30 were examined similarly to the intermediates. Enantiotropic and monotropic phases were observed in the $N, N$-diethanol and $N$-ethyl- $N$-ethanol quaternary ammonium salts bearing alkoxy azobenzene. The $N, N$-diethanol quaternary ammonium salt exhibited enantiotropic phases such as smectic $\mathrm{C}$ and smectic B phases upon heating. In the case of the $N$-ethyl- $N$-ethanol quaternary ammonium salt $\mathbf{2 4}$, it exhibited monotropic phases (schlieren texture of SmC phase) as shown in Fig. 9a.

The natural focal conic texture exhibiting the SmA phase of compound 26 and the SmC phase of compound 27 are shown in Fig. $9 \mathrm{~b}$ and c, respectively. The $N, N$-diethyl quaternary ammonium salt-based azobenzenes are non-liquid crystalline in nature due to the absence of a hydroxyl group on their head group. Hence, the mesophases changes in their properties may

Table 3 Phase transition temperatures, mesophase types, and transition enthalpies $\left[\Delta H / \mathrm{kJ}^{\mathrm{mol}}{ }^{-1}\right]$ of compounds $13-21$ upon heating ${ }^{a}$<smiles>[R7]CCN(CC[R7])CCCCCCOc1ccc(N=Nc2ccc(OCC)cc2)cc1</smiles>

\begin{tabular}{|c|c|c|c|c|}
\hline 13 & 7 & $-\mathrm{OH}$ & $-\mathrm{OH}$ & H: Cr 106.37 [24.18] Iso \\
\hline 14 & 8 & $-\mathrm{OH}$ & $-\mathrm{OH}$ & H: Cr 107.31 [27.29] Iso \\
\hline 16 & 7 & $-\mathrm{OH}$ & $-\mathrm{H}$ & $\mathrm{H}: \mathrm{Cr} 73.28[18.76]$ Iso \\
\hline 17 & 8 & $-\mathrm{OH}$ & $-\mathrm{H}$ & $\mathrm{H}: \mathrm{Cr} 74.51$ [19.97] Iso \\
\hline 18 & 12 & $-\mathrm{OH}$ & $-\mathrm{H}$ & $\mathrm{H}: \mathrm{Cr} 87.79[37.55] \mathrm{SmC} 104.46[4.81] \mathrm{SmA} 115.52$ [2.72] Iso \\
\hline 21 & 12 & $-\mathrm{H}$ & $-\mathrm{H}$ & $\mathrm{H}: \mathrm{Cr} 79.76[44.32]$ Iso \\
\hline
\end{tabular}

${ }^{a}$ Abbreviations see Table 1. 

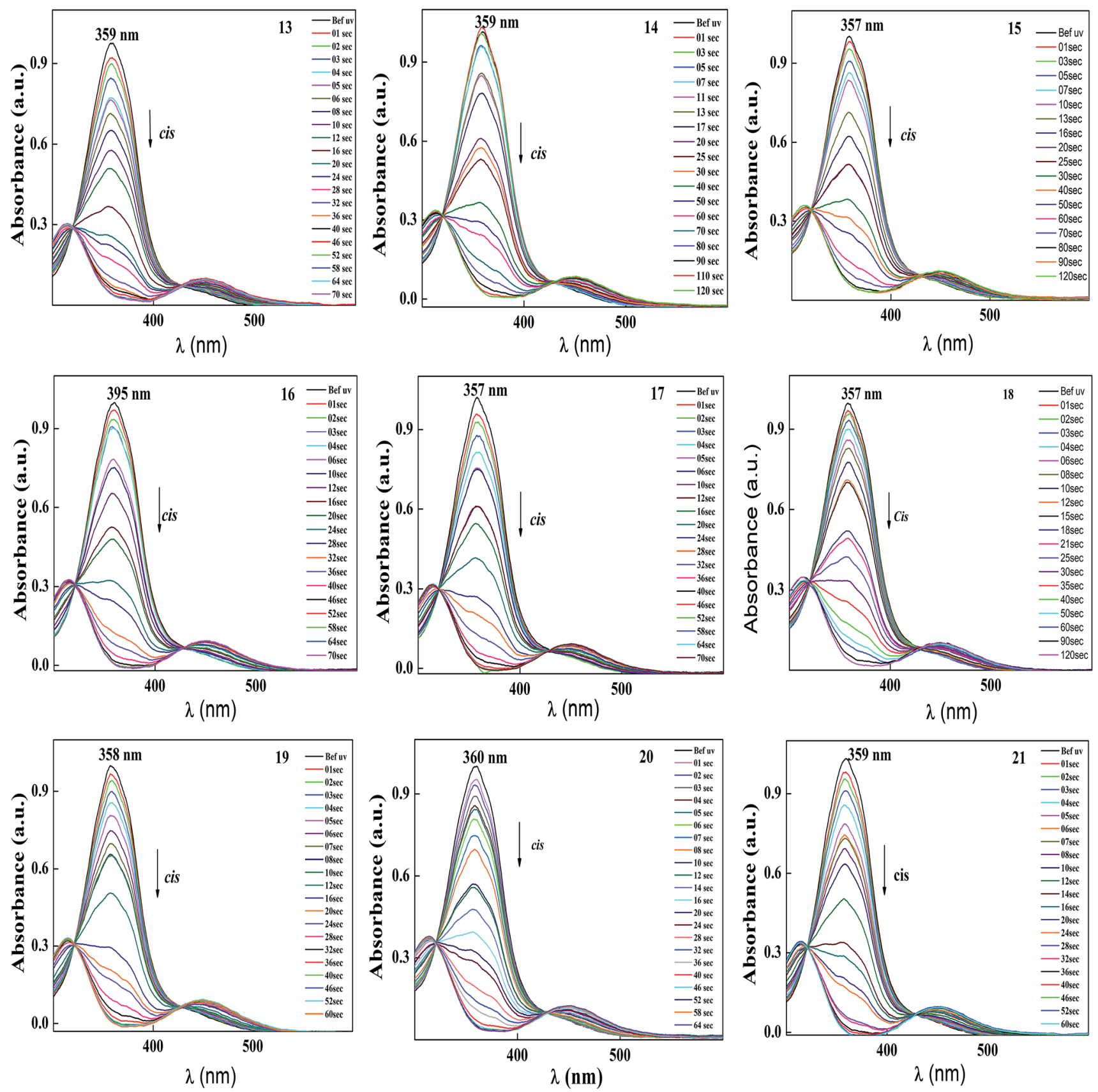

Fig. 6 Normalized absorption spectra of compound 13-21 as a function of UV irradiation time. Intensity of the UV illumination is $1 \mathrm{~mW} \mathrm{~cm}^{-2}$.

be due to the polar group present in the quaternary ammonium salt. The phase transition temperature and transition enthalpies were determined via DSC and the summarized data given in Table 5.

To better understand the mesophases, the proposed model, as shown in Fig. 10 shows the formation of non-tilted smectic A and tilted smectic $\mathrm{C}$ phases. The smectic A mesophase was observed in all the compounds bearing a hydroxyl group on their terminal head group. The influence of the terminal alkoxy chain $(n>10)$ length on the formation of ionic liquid crystals with the smectic $\mathrm{C}$ phase was previously reported. ${ }^{41}$ According to the zigzag model by Wulf, ${ }^{42}$ the appearance of the smectic $\mathrm{C}$ phase occurs by increasing the length of the terminal chain. For compounds $\mathbf{2 4}$ and $\mathbf{2 7}$, which have the highest chain length at the terminal end $(n=12)$, evidence was observed for the formation of the smectic $\mathrm{C}$ phase and also similar results were observed in the case of compounds $\mathbf{1 5}$ and $\mathbf{1 8}$. In the case of the substituent $\mathrm{X}=\mathrm{H}$ on the head group, no liquid crystalline properties were observed because the hydroxyl group plays a major role in the mesomorphism.

2.4.2 Photoswitching properties. The photoswitching studies of the azobenzene-mesogen-bearing ionic liquids were investigated similarly to the intermediates. Before and after UV illumination, the absorption spectra of 22-30 were recorded by 

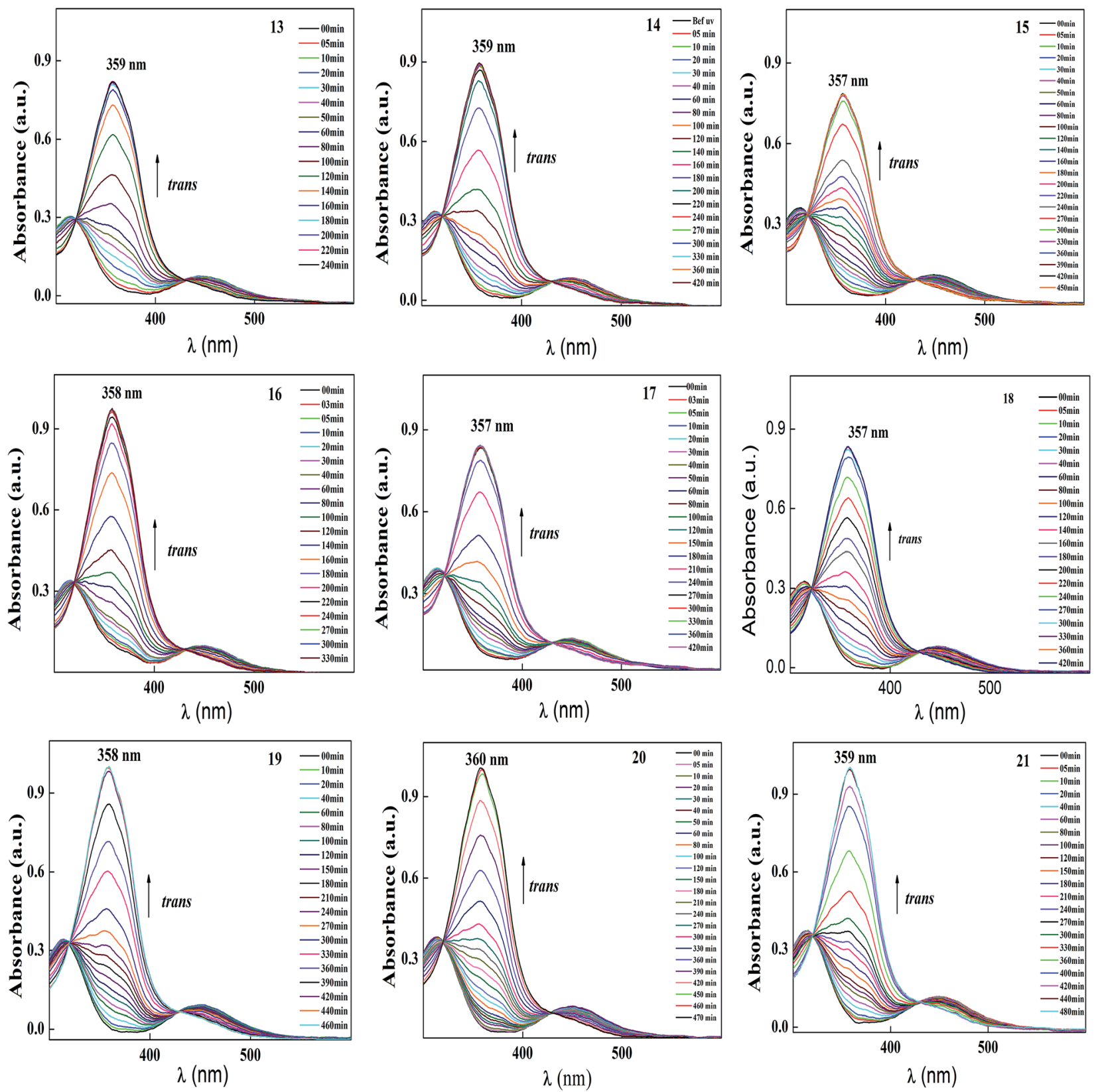

Fig. 7 Normalized absorption spectra of compounds 13-21 as a function of recovery time during thermal back relaxation.

UV-vis spectroscopy. There were no notable changes in the peak wavelength, and the characteristic peak absorption wavelength at $356-359 \mathrm{~nm}$ originated from the $\pi-\pi *$ transition of the trans isomer. After UV irradiation, the absorption peak at $356 \mathrm{~nm}$ gradually decreased due to the transformation of the cis isomer for compound 22. After $25 \mathrm{~s}$ of irradiation, the trans isomer reached the photo equilibrium state in the isomerization reaction.

After reaching the photosaturation state, the reverse transformation of the cis isomer occurred in the dark and the thermal back relaxation was recorded with respect to the recovery time of the trans isomer. Similar results were also observed to that of the other compounds, and the normalized absorption spectra of compounds 22-30 are given in Fig. 11. The peak absorbance versus time was plotted by extracting data from the absorption spectra of compounds 22-30 upon UV illumination as shown in graph (e) (see Fig. 11). The photoconversion efficiency for trans-cis isomerization of the azobenzene-based ionic liquids was determined using eqn (1). All the compounds showed good conversion efficiency, suggesting the ionic liquids exhibit quick photoresponsive behaviour in solution. In the case of compound 30, the conversion efficiency was about 94\%, whereas, compound 27 showed $66 \%$. The presence of a hydroxyl group on the head group reduced the cis isomer ratio in the photoequilibrium state during photoisomerization. Therefore, the presence of a hydroxyl group and 

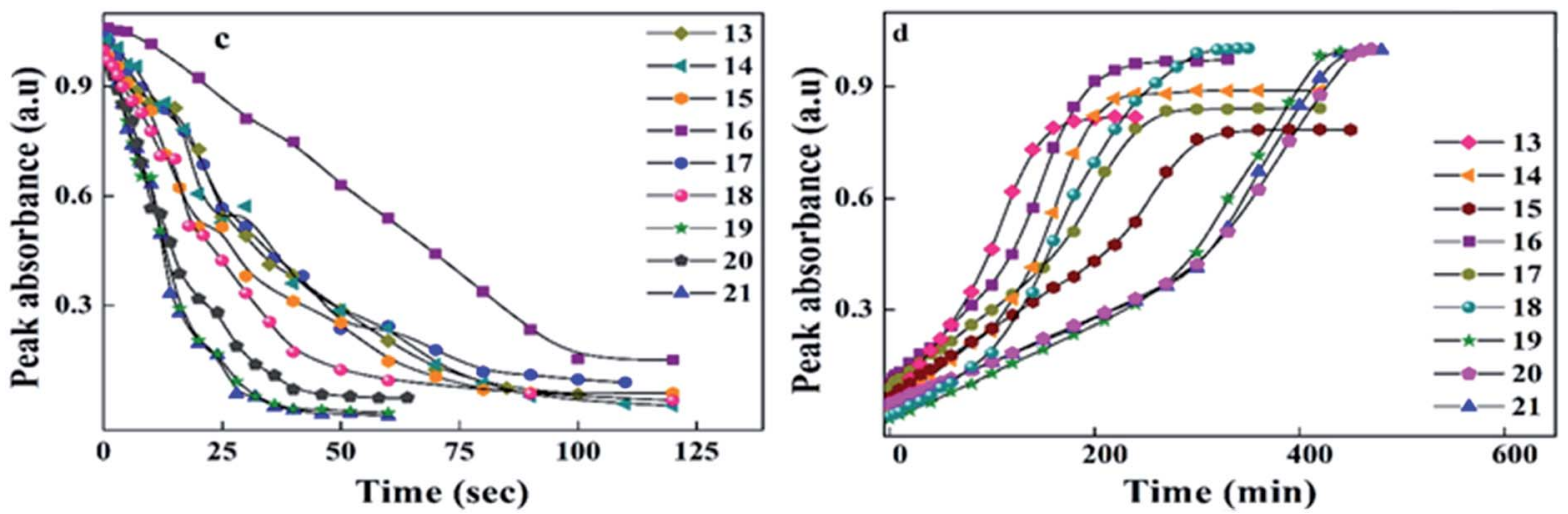

Fig. 8 Peak absorbance with respect to time graph (c) peak absorbance plot for trans-cis isomerization, with the data extracted from the absorption spectra (Fig. 6) of 13-21 during UV illumination and graph (d) peak absorbance plot for cis-trans isomerization, with the data extracted from the absorption spectra (Fig. 7) of 13-21 during thermal back relaxation.

Table 4 The summarized data of $E / Z$ isomerisation, thermal back relaxation and its photoconversion efficiency

\begin{tabular}{llll}
\hline & $E / Z$ & $\begin{array}{l}\text { Thermal back relaxation } \\
\text { Compound code }\end{array}$ & \\
& isomerization in s & CE min \\
\hline $\mathbf{1 3}$ & 70 & 180 & 96.00 \\
$\mathbf{1 4}$ & 80 & 240 & 96.77 \\
$\mathbf{1 5}$ & 85 & 330 & 94.47 \\
$\mathbf{1 6}$ & 90 & 240 & 99.49 \\
$\mathbf{1 7}$ & 85 & 270 & 98.92 \\
$\mathbf{1 8}$ & 56 & 320 & 94.47 \\
$\mathbf{1 9}$ & 40 & 440 & 99.82 \\
$\mathbf{2 0}$ & 46 & 460 & 95.20 \\
$\mathbf{2 1}$ & 52 & 440 & 94.96
\end{tabular}

the alkoxy chain length play a significant role in photoisomerization. A summary of the photoconversion efficiency data for the trans-cis isomerization is shown in Table 6.

Among all the compounds, 30 showed the best thermal back relaxation time of about $590 \mathrm{~min}$, whereas, the cis isomer of compound 22 was not fully transformed into the trans isomer. The terminal head group of the azobenzene unit acts as an electron withdrawing group, which can reduce the isomerization energy barrier and accelerate the isomerization of azobenzene. However, in the case of 22, the presence of a hydroxyl group reduced the electron withdrawing character of the head group. As a result, the cis isomer was not fully converted into its original state and also could be phase involved during thermal back relaxation due to the molecules being arranged in an ordered layer structure (smectic phase). Furthermore, the normalized absorption spectra for the thermal back relaxation of the azobenzene-based ionic liquids were investigated in detail (Fig. 12). According to Fig. 12, after the photoequilibrium state, the cis isomer of 22-27 did not fully transform back to its original state due to the formation of intermolecular hydrogen bonding in the hydroxyl group present on its head group.

A schematic diagram of the light-induced photoisomerization of the azo compounds is shown in Fig. 13. The polar substituent $(\mathrm{X}=\mathrm{OH})$ on the head group of the azo compounds of the cis isomer could not achieve its original state due to the layered arrangement of molecules (smectic A phase) restricting the free rotation of the molecule during thermal back relaxation. In the case of 29 and 30, they possess random arrangements due to the absence of a hydroxyl group on their head group and they exhibited long thermal back relaxation.

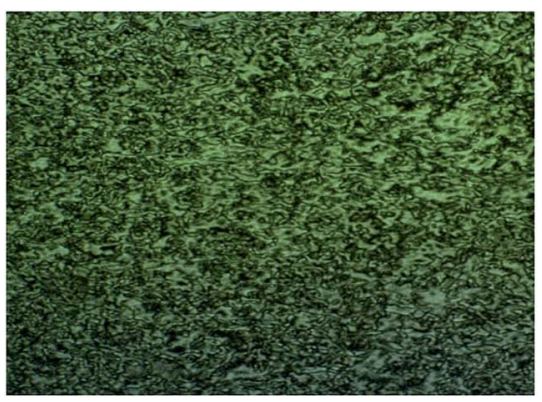

(a)

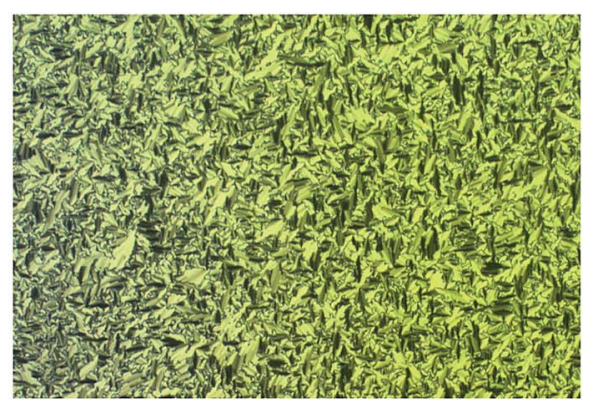

(b)

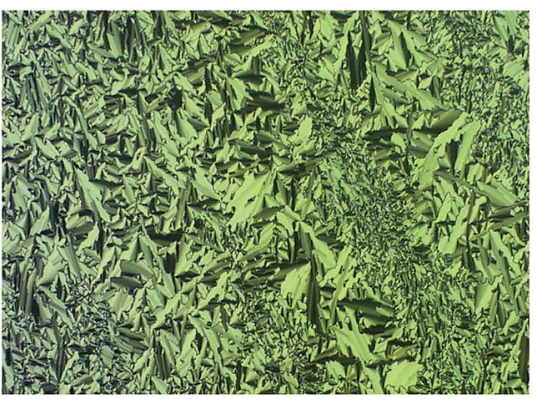

(c)

Fig. 9 Polarized optical images. (a) Schlieren texture of SmC phase observed in compound 24, (b) natural focal conic texture typical of SmA for compound 26 and (c) SmC phase as seen in compound 27. Magnification used is $10 \times$. 
Table 5 Phase transition temperatures, mesophase types, and transition enthalpies $\left[\Delta H / \mathrm{kJ} \mathrm{mol}^{-1}\right]$ of compounds $22-30$ upon heating ${ }^{a}$

\begin{tabular}{|c|c|c|c|c|}
\hline Compound code & $n$ & $\mathrm{R}^{\prime}$ & $\mathrm{R}^{\prime \prime}$ & Phase transitions $T /{ }^{\circ} \mathrm{C}\left[\Delta H / \mathrm{kJ} \mathrm{mol}^{-1}\right]$ \\
\hline 23 & 8 & $-\mathrm{OH}$ & $-\mathrm{OH}$ & H: Cr $141.0[13.80] \operatorname{SmA} 220.92[2.22]$ Iso \\
\hline 24 & 12 & $-\mathrm{OH}$ & $-\mathrm{OH}$ & H: Cr $135.98[45.11]$ SmC 132.15 [1.66] SmA 194.17 [3.32] Isc \\
\hline 25 & 7 & $-\mathrm{OH}$ & $-\mathrm{H}$ & $\mathrm{H}: \mathrm{Cr} 158.09[42.26] \mathrm{SmA} 185.98$ [0.91] Iso \\
\hline 26 & 8 & $-\mathrm{OH}$ & $-\mathrm{H}$ & H: Cr $148.91[32.42] \mathrm{SmA} 199.56[0.89]$ Iso \\
\hline 27 & 12 & $-\mathrm{OH}$ & $-\mathrm{H}$ & $\mathrm{H}: \mathrm{Cr} 52.81[11.23] \mathrm{SmC} 111.71$ [6.64] Iso \\
\hline 28 & 7 & $-\mathrm{H}$ & $-\mathrm{H}$ & $\mathrm{H}: \mathrm{Cr} 81.72[21.53]$ Iso \\
\hline
\end{tabular}
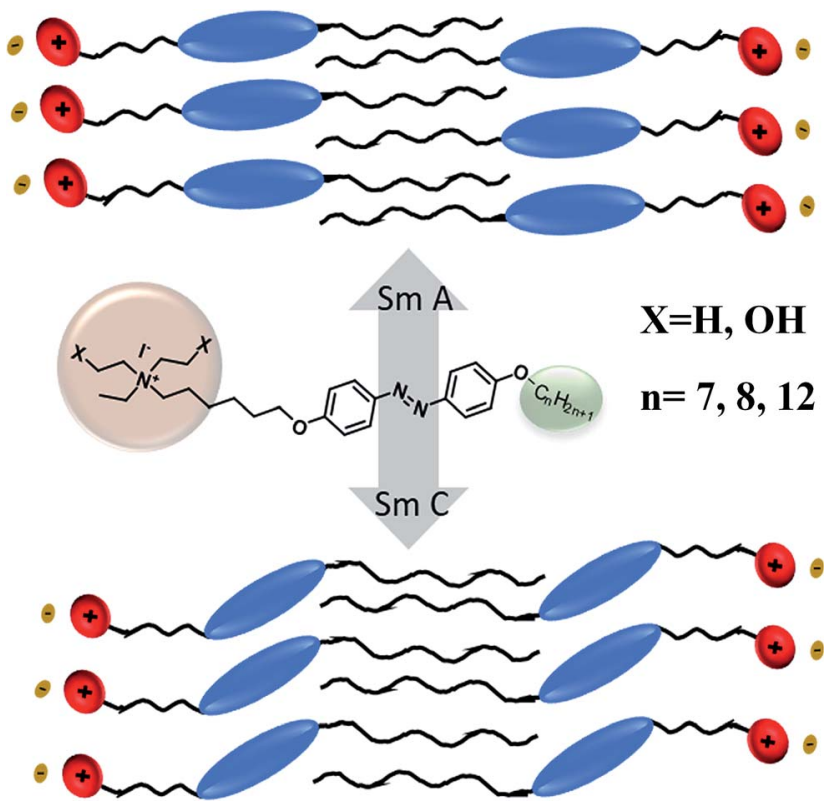

Fig. 10 Proposed model showing the appearance of liquid crystalline phases (SmA and SmC phases).

\subsection{Kinetic studies}

For azo compounds 10-30, it is necessary to study the kinetics of their cis-trans isomerisation, which was carried out thermally using UV-vis spectroscopy. ${ }^{43}$ The experiment was carried out in the dark at room temperature of $27^{\circ} \mathrm{C}$ and chloroform was used as the solvent. The unimolecular thermal cis-trans isomerisation in the dark obeys eqn (2).

$$
-K_{c-t} t=\ln \frac{A_{(\infty)}-A_{(t)}}{A_{(\infty)}-A_{(0)}}
$$

where $A_{t}, A_{0}$ and $A_{\infty}$ are the change in absorbance at time $t$, time zero and infinite time, respectively. $t$ is the relaxation time of the respective cis isomer. The time region in Fig. 14 shows that the reaction is first order in the case of $\mathbf{1 0}$, whereas in the case of $\mathbf{1 1}$ and 12, the reactions are first order at a certain time and thereafter, due to the long thermal back relaxation it is deviated from first order to second order kinetics. During thermal back relaxation, temperature may play a significant role in deviating from first order. ${ }^{40}$ As shown in Fig. 14, the reaction is first order at a certain time and deviates to second order due to the cis isomer being thermally stable for some time due to the pushpush-type of effect arising in compounds 13-21.

In the case of compounds 22-30, most of the reaction is first order except for compound 30, which exhibited a push-pulltype effect due to the head group of the ionic liquid acting as an electron withdrawing group. In the case of 22-27, the reaction was first order due to the presence of a hydroxyl group exhibiting the pull-pull-type effect, which could not reduce the isomerization energy barrier and the acceleration of the isomerization of azobenzene was negligible.

\subsection{Optical storage device}

Spectral investigation on a real device was also conducted to determine the potential of the materials. Fabrication of the cell involved ITO coated, polyimide rubbed sandwiched glass plates with the desired thickness of around $\sim 5 \mu \mathrm{m}$. The guest-host mixture was prepared, where azobenzene molecules acted as the guest and the room temperature liquid crystal acted as the host material.

As a representative compound, we took compound $\mathbf{3 0}$ as our guest light sensitive molecules since it showed the best properties during the photoisomerization studies. The mixture consisted of $5 \%$ of compound $\mathbf{3 0}$ (which is a light-sensitive molecule but non-liquid crystalline in nature) mixed with $95 \%$ MLC-6873-100 (room temperature commercial liquid crystal). This mixture exhibited a room temperature nematic mesophase. The prepared mixture was capillary filled in a cell, which was previously fabricated. 

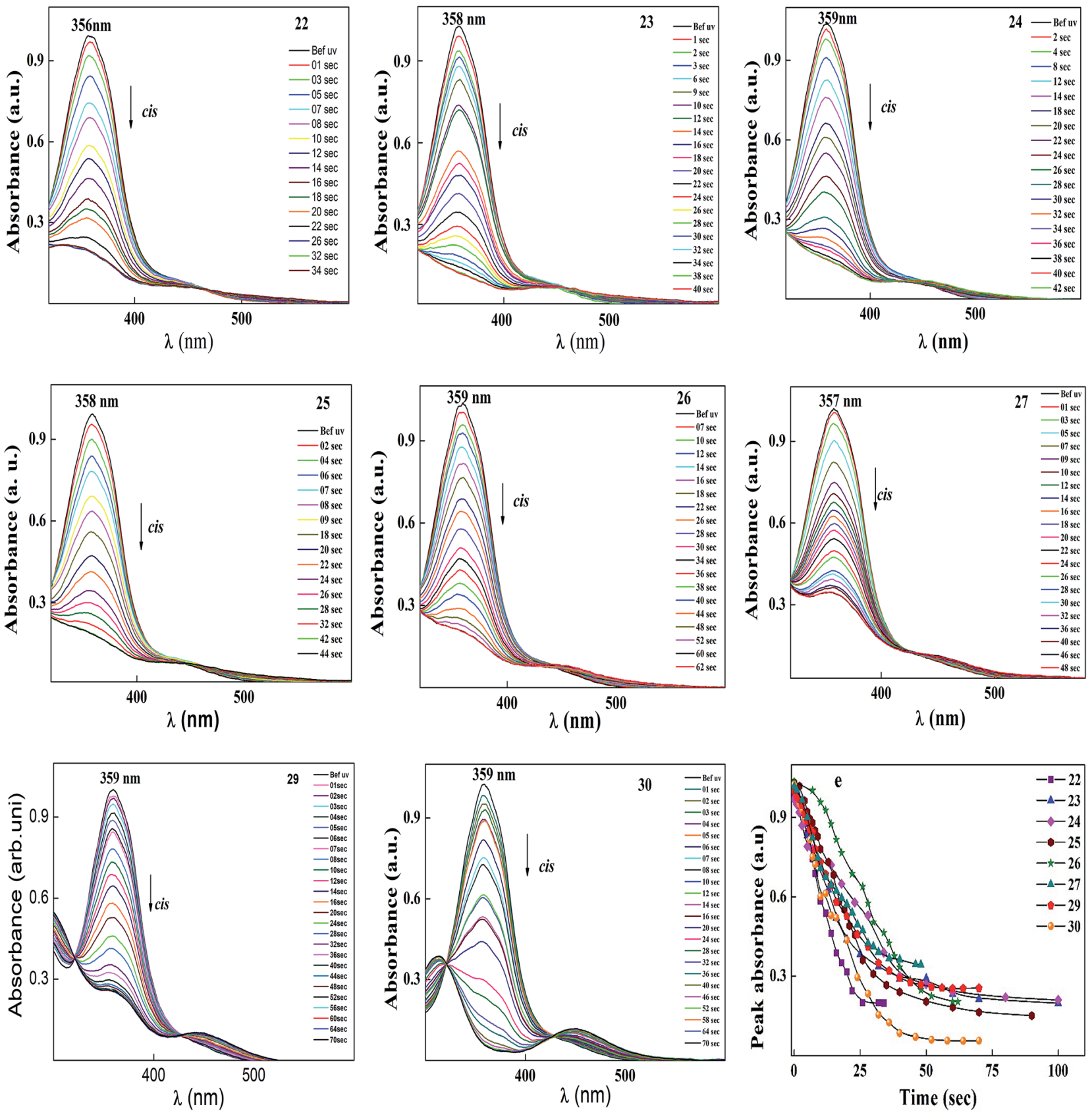

Fig. 11 Normalized absorption spectra of compounds 22-30 as a function of UV irradiation time. Graph (e) peak absorbance plot for trans-cis isomerization extracted from the absorption spectra (in this figure) of 22-30 upon UV illumination. Intensity of the UV light used was $1 \mathrm{~mW}^{\mathrm{cm}}{ }^{-2}$.

Table 6 The summarized data of $E / Z$ isomerisation, thermal back relaxation and its photoconversion efficiency

\begin{tabular}{llll}
\hline & $E / Z$ & $\begin{array}{l}\text { Thermal back relaxation } \\
\text { Compound code }\end{array}$ & CE \% \\
\hline $\mathbf{2 2}$ & 25 & 60 & 80.20 \\
$\mathbf{2 3}$ & 32 & 160 & 80.64 \\
$\mathbf{2 4}$ & 46 & 210 & 77.42 \\
$\mathbf{2 5}$ & 32 & 140 & 85.43 \\
$\mathbf{2 6}$ & 48 & 240 & 80.33 \\
$\mathbf{2 7}$ & 36 & 270 & 66.18 \\
$\mathbf{2 9}$ & 44 & 390 & 74.55 \\
$\mathbf{3 0}$ & 46 & 590 & 94.43
\end{tabular}

The $E / Z$ and $Z / E$ photoisomerization behaviour of the solid cell is depicted in Fig. 15. The intensity used for achieving photosaturation was around $1.2 \mathrm{~mW} \mathrm{~cm}^{-2}$ and it took $\sim 80 \mathrm{~s}$ to reach the photosaturation state (Fig. 15a and b). In contrast, back relaxation, which occurred in the absence of light, took around $\sim 400 \mathrm{~min}$ to reach the original position (Fig. 15c and d).

To see the effect of thermal back relaxation, we fabricated an optical storage device with the above mixture. Previously prepared ITO coated, unidirectionally rubbed polyimide layers were sandwiched between two glass plates with a uniform thickness of $\sim 5 \mu \mathrm{m}$. The device, as depicted in 

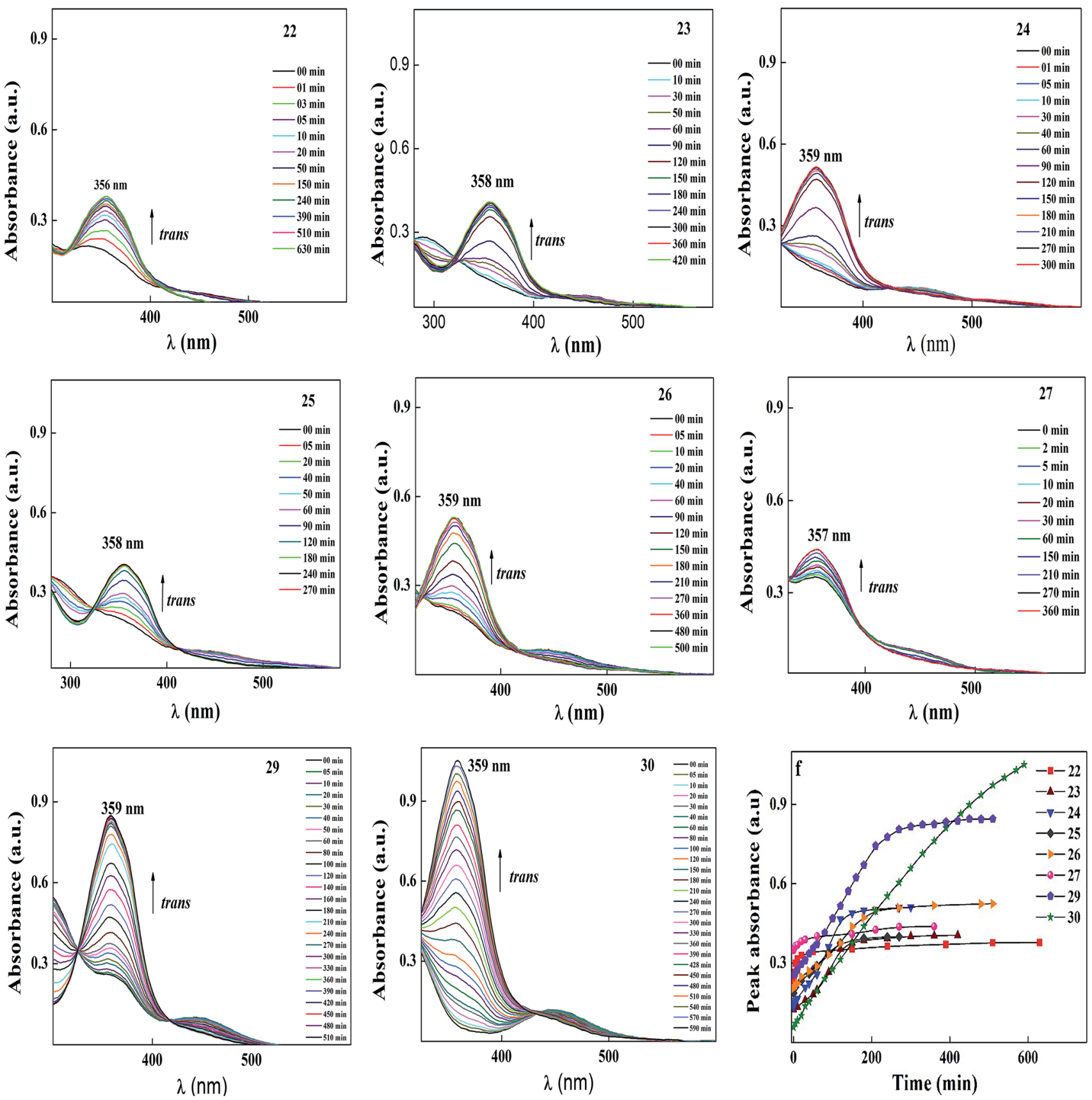

Fig. 12 Normalized absorption spectra of compounds 22-30 as a function of recovery time during thermal back relaxation. Graph (f) peak absorbance plot for cis-trans isomerization extracted from the absorption spectra (in this figure) of 22-30 during thermal back relaxation.

Fig. 16, showed bright and dark regions after illumination

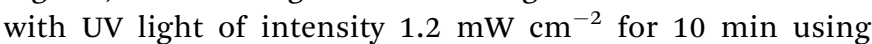
suitable masks. As can be seen from the figure, the exposed region where UV light is illuminated transforms from an ordered nematic state to a disordered isotropic state (black region), whereas the masked region remains in the nematic phase (bright region). To transfer back to the original nematic phase from the isotropic phase, the device took around 250 min, showing the potential of the optical rewriting capabilities of the materials.

\subsection{Proposed model for guest-host effect}

When UV light of $365 \mathrm{~nm}$ was illuminated on the composite mixture of azobenzene and liquid crystal molecules, the energetically stable trans isomer (order state) transformed to the cisisomer (disorder state). The guest-host effect of azobenzene and liquid crystal molecules is schematically depicted Fig. 17, which shows that the reverse transformation of the cis isomer is not easy to reach its original state due to the presence of hydrophobic and hydrophilic head groups on the azo molecules. 


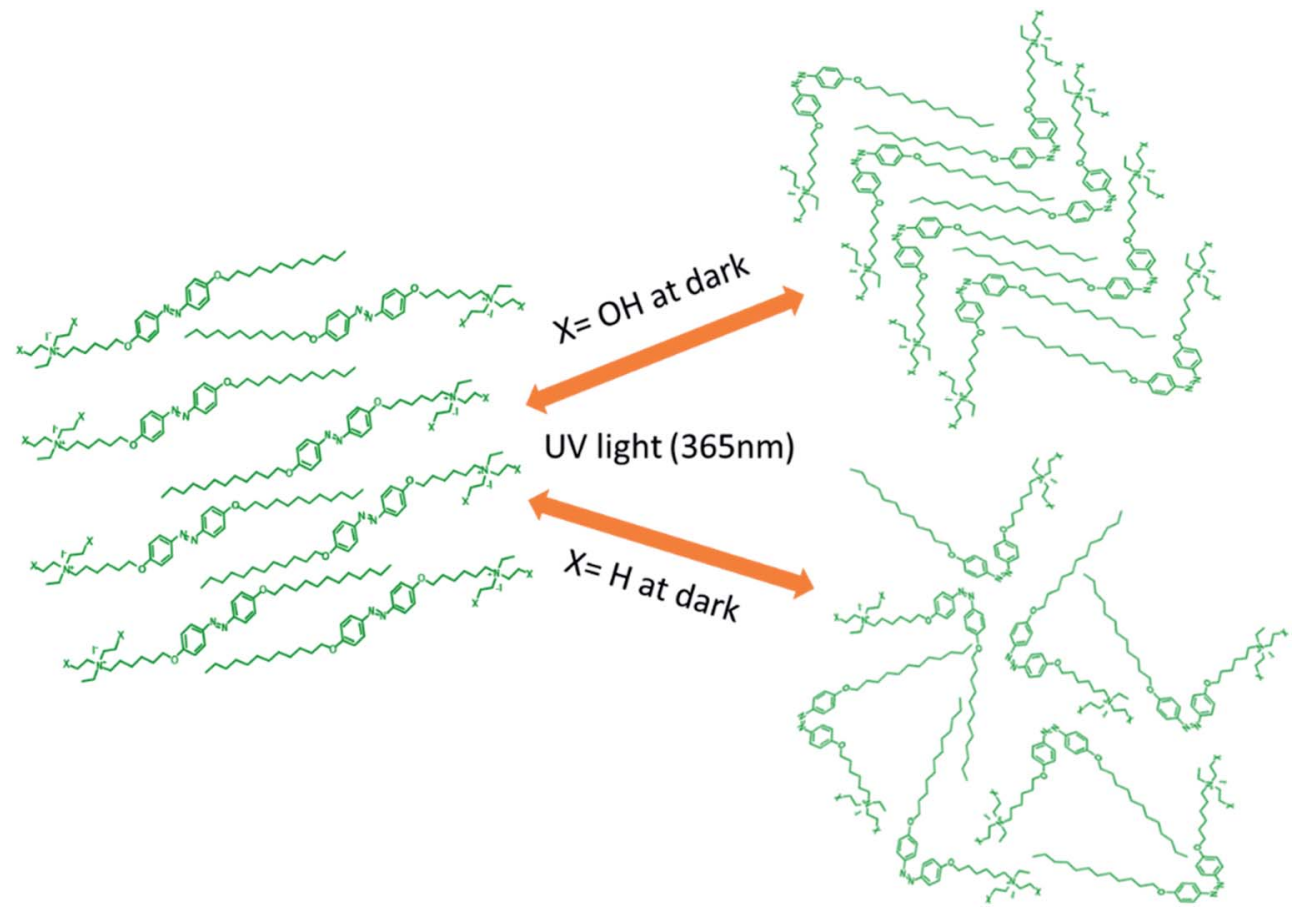

Fig. 13 Schematic diagram of the light-induced trans-cis isomerization of compounds 22-30 (if $\mathrm{X}=\mathrm{OH}$, layered order arrangements of molecules and if $X=H$, molecules are randomly arranged).

\section{Experimental}

\subsection{Materials and methods}

$N, N$-Dimethylethanolamine (99\%), ethanol (99.9\%), ethyl iodide (98\%), 2-propanol (99\%), $\mathrm{HCl}$ conc. (35\%), $\mathrm{NaNO}_{2}(99 \%)$, phenol (98\%) $\mathrm{K}_{2} \mathrm{CO}_{3}$ (99.5\%), $\mathrm{Na}_{2} \mathrm{CO}_{3}(99.5 \%), \mathrm{NaOH}(98 \%), 1-$ bromododecane (99\%), 1-bromoheptane (99\%), 1-bromooctane (99\%) and 1,6-dibromohexane (99\%) were purchased from Acros Organics and used without further purification. Petroleum ether (b.p. 60-90 ${ }^{\circ} \mathrm{C}$ ), acetonitrile (99.9\%), dichloromethane (99.9\%), acetone (99\%) and ethyl acetate (99\%) were commercial products obtained from Acros Organics. ${ }^{1} \mathrm{H}$ NMR $(400 \mathrm{MHz})$ and ${ }^{13} \mathrm{C} \mathrm{NMR}(100 \mathrm{MHz})$ were recorded on a Bruker $400 \mathrm{MHz}$ Ultrashield ${ }^{\mathrm{TM}}$ spectrometer. Elemental analysis was performed using a CHN elemental analyser.
3.1.1 General synthetic procedure for 4-acetamidophenoxyalkanes (1-3). To a $250 \mathrm{~mL}$ round-bottom flask containing 4acetamidophenol (1.0 equiv.) in dry acetone, anhydrous potassium carbonate (3.0 equiv.), a catalytic amount of potassium iodide and the corresponding 1-bromoalkane (1.1 equiv.) were added. The reaction mixture was refluxed for $48 \mathrm{~h}$. The reaction progress was monitored by TLC. After completion of the reaction, excess solvent was removed using a rotatory evaporator. The crude product was washed with distilled water to remove excess potassium carbonate and the residue was filtered and dried. Excess 1-bromoalkane was removed by washing the residue with $n$-hexane. The crude product was purified by column chromatography using ethyl acetate/hexane (v/v, $30: 70)$ to yield compounds $\mathbf{1 - 3}$.

(1) $(n=7)$ yield: $71.5 \% .{ }^{1} \mathrm{H}$ NMR $\left(400 \mathrm{MHz}, \mathrm{CDCl}_{3}\right) \delta / \mathrm{ppm}$ 7.38-7.32 (m, 2H), 7.13 (s, 1H), 6.88-6.80 (m, 2H), 3.96-3.88
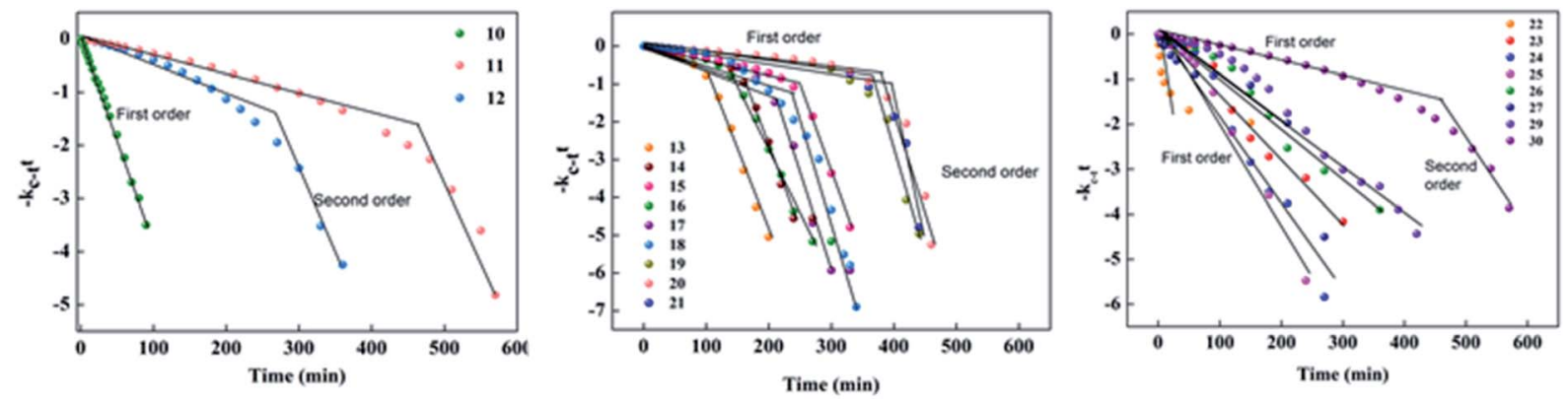

Fig. 14 First-order plot for the thermal back relaxation of compounds 10-30 measured at room temperature. 

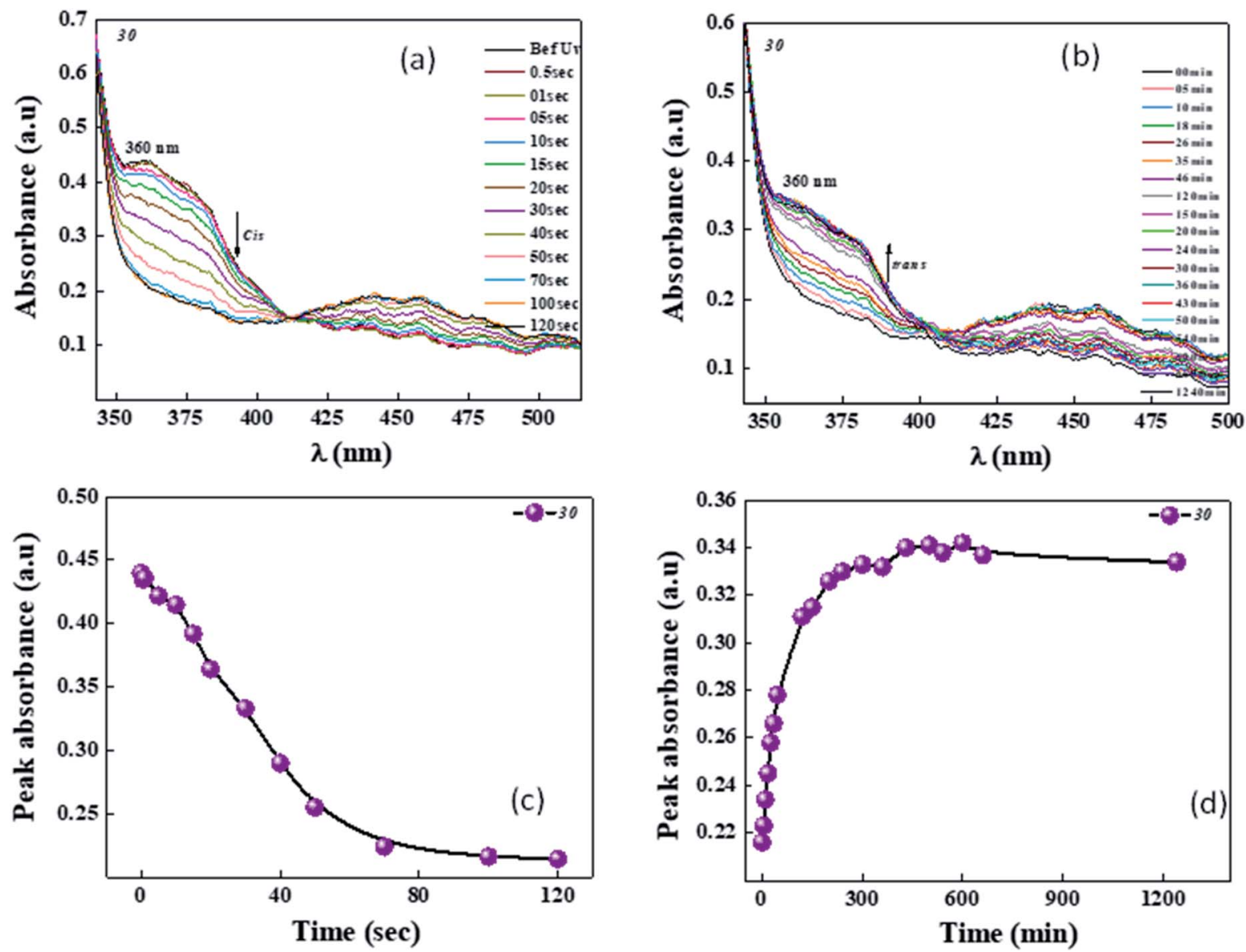

Fig. $15 E / Z$ ( $a$ and $b$ ) and $Z / E$ ( $c$ and d) photoisomerization of the solid cell filled with the mixture of compound 30 and room temperature liquid crystals as guest-host combination. Intensity used was around $1.2 \mathrm{~mW} \mathrm{~cm}^{-2}$, where the light-sensitive moiety (which is compound 30 ) acts like the guest and MLC-6873-100, which is a room temperature liquid crystal, acts as the host.

$(\mathrm{m}, 2 \mathrm{H}), 2.14(\mathrm{~s}, 3 \mathrm{H}), 1.80-1.69(\mathrm{~m}, 2 \mathrm{H}), 1.43(\mathrm{dt}, J=15.1$, $6.6 \mathrm{~Hz}, 2 \mathrm{H}$ ), 1.33 (ddd, $J=15.0,8.6,4.6 \mathrm{~Hz}, 6 \mathrm{H}), 0.88(\mathrm{t}$, $J=6.9 \mathrm{~Hz}, 3 \mathrm{H})$.
(2) ( $n=8$ ) yield: $68.82 \% .{ }^{1} \mathrm{H}$ NMR $\left(400 \mathrm{MHz}, \mathrm{CDCl}_{3}\right) \delta / \mathrm{ppm} 7.39-$ $7.33(\mathrm{~m}, 2 \mathrm{H}), 6.89-6.78(\mathrm{~m}, 2 \mathrm{H}), 3.97-3.84(\mathrm{~m}, 2 \mathrm{H}), 1.81-1.68(\mathrm{~m}$, $2 \mathrm{H}), 1.49-1.37$ (m, 2H), 1.37-1.20 (m, 8H), 0.87 (t, $J=6.9 \mathrm{~Hz}, 3 \mathrm{H})$.

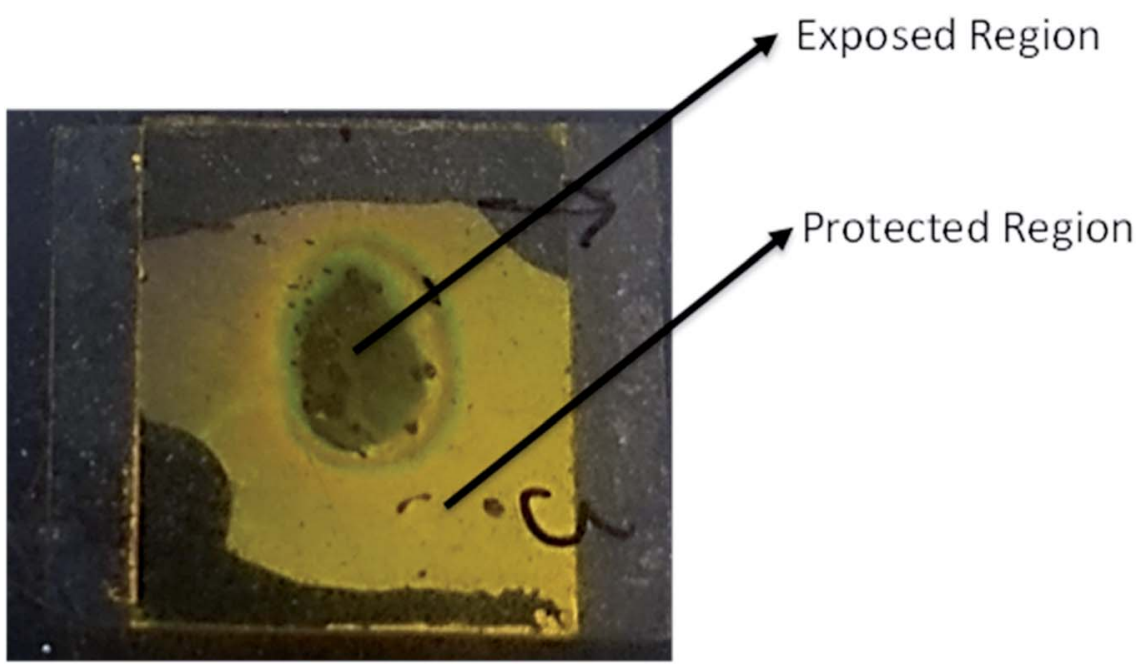

Fig. 16 Demonstration of the optical storage device described herein through UV illumination together with a photomask. Bright region corresponds to the non-illuminated area, whereas, the dark region corresponds to the UV illuminated area. Material transformed from the nematic to isotropic phase during illumination, showing excellent dark and bright states between them. 


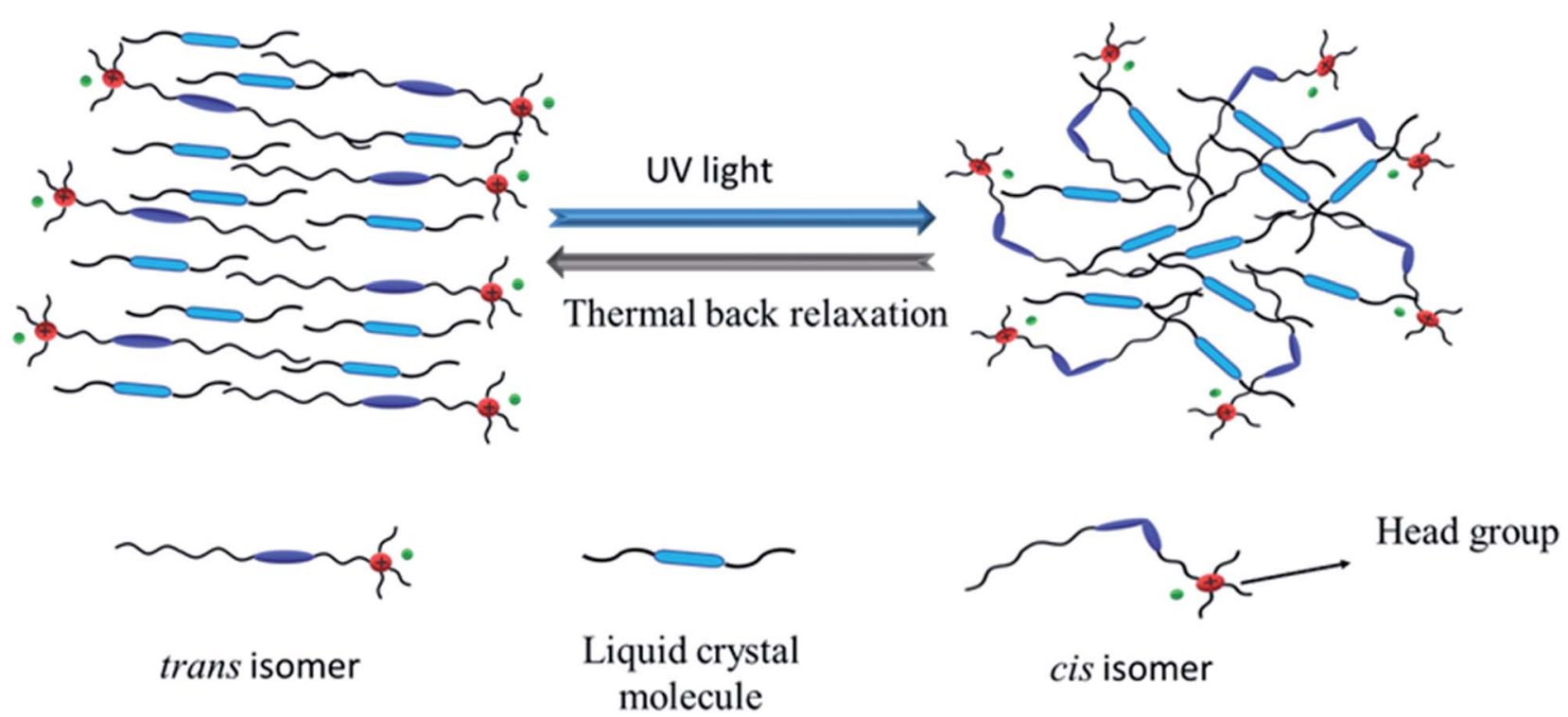

Fig. 17 Schematic diagram of the guest-host effect of the azobenzene-based ionic liquid and liquid crystal molecules.

(3) $(n=12)$ yield: $83.5 \%{ }^{1} \mathrm{H}$ NMR $\left(400 \mathrm{MHz}, \mathrm{CDCl}_{3}\right) \delta / \mathrm{ppm}$ 7.37-7.31 (m, 2H), $7.12(\mathrm{~s}, 1 \mathrm{H}), 6.86-6.82(\mathrm{~m}, 2 \mathrm{H}), 3.98-3.88(\mathrm{~m}$, $2 \mathrm{H}), 2.14(\mathrm{~s}, 3 \mathrm{H}), 1.81-1.67(\mathrm{~m}, 2 \mathrm{H}), 1.49-1.38(\mathrm{~m}, 2 \mathrm{H}), 1.38-1.22$ $(\mathrm{m}, 17 \mathrm{H}), 0.87(\mathrm{t}, J=6.9 \mathrm{~Hz}, 3 \mathrm{H})$.

3.1.2 General synthetic procedure for 4-alkyloxyanilines (46). To a $250 \mathrm{~mL}$ round-bottom flask containing the corresponding 4-acetamidophenoxyalkanes (1-3), sodium hydroxide pellets in ethanol were added. The reaction mixture was refluxed for $24 \mathrm{~h}$. The reaction progress was monitored by TLC. After completion of the reaction, the excess solvent was evaporated using a rotatory evaporator. The crude product was purified via recrystallization from ethanol.

(4) $(n=7)$ yield: ${ }^{1} \mathrm{H}$ NMR $\left(400 \mathrm{MHz}, \mathrm{CDCl}_{3}\right) \delta / \mathrm{ppm} 6.76-6.69$ $(\mathrm{m}, 2 \mathrm{H}), 6.66-6.58(\mathrm{~m}, 2 \mathrm{H}), 4.06(\mathrm{t}, J=6.6 \mathrm{~Hz}, 2 \mathrm{H}), 1.73(\mathrm{~m}, 2 \mathrm{H})$, 1.45-1.36 (m, 2H), 1.36-1.22 (m, 6H), $0.88(\mathrm{t}, J=6.9 \mathrm{~Hz}, 3 \mathrm{H})$.

(5) $(n=8)$ yield: $80 \% .{ }^{1} \mathrm{H} \mathrm{NMR}\left(400 \mathrm{MHz}, \mathrm{CDCl}_{3}\right) \delta / \mathrm{ppm} 6.76-$ $6.70(\mathrm{~m}, 2 \mathrm{H}), 6.65-6.60(\mathrm{~m}, 2 \mathrm{H}), 4.04(\mathrm{t}, J=6.6 \mathrm{~Hz}, 2 \mathrm{H}), 1.74(\mathrm{~m}$, $2 \mathrm{H}), 1.43(\mathrm{~m}, 2 \mathrm{H}), 1.30-1.26(\mathrm{~m}, 8 \mathrm{H}), 0.87(\mathrm{t}, J=6.9 \mathrm{~Hz}, 3 \mathrm{H})$.

(6) $(n=12)$ yield: $70 \% .{ }^{1} \mathrm{H}$ NMR $\left(400 \mathrm{MHz}, \mathrm{CDCl}_{3}\right) \delta / \mathrm{ppm}$ 6.76-6.70 (m, 2H), 6.65-6.59 (m, 2H), $4.06(\mathrm{t}, J=6.6 \mathrm{~Hz}, 2 \mathrm{H})$, $1.74(\mathrm{~m}, 2 \mathrm{H}), 1.43(\mathrm{~m}, 2 \mathrm{H}), 1.29-1.26(\mathrm{~m}, 16 \mathrm{H}), 0.87(\mathrm{t}, J=$ $6.9 \mathrm{~Hz}, 3 \mathrm{H})$.

3.1.3 General synthetic procedure for 4 - $\left[\left(4^{\prime}\right.\right.$-alkyloxyphenyl $)$ diazenyl]phenols, 7-9. In a $250 \mathrm{~mL}$ round-bottom flask, the corresponding 4-alkyloxyanilines, 4-6 (1.0 equiv.) were dissolved in a mixture of acetone $(100 \mathrm{~mL})$ and concentrated hydrochloric acid. The reaction mixture was stirred for $1 \mathrm{~h}$ with the temperature of the mixture maintained below $0{ }^{\circ} \mathrm{C}$. A cold solution of phenol (1.0 equiv.), sodium hydroxide (1.0 equiv.) and sodium carbonate (1.0 equiv.) was then added dropwise to the reaction mixture and it was stirred for another hour at $0{ }^{\circ} \mathrm{C}$, thereafter the ice-water bath was removed, and it was stirred at room temperature overnight. The reaction mixture was then neutralized with an aqueous solution of sodium hydroxide, upon which a reddish-brown precipitated was formed. The crude products were filtered, washed with distilled water and recrystallized from $n$-hexane to yield compounds 7-9.

(7) $(n=7)$ yield: ${ }^{1} \mathrm{H}$ NMR $\left(400 \mathrm{MHz}, \mathrm{CDCl}_{3}\right) \delta / \mathrm{ppm} 7.87-7.77$ $(\mathrm{m}, 4 \mathrm{H}), 7.01-6.85(\mathrm{~m}, 4 \mathrm{H}), 4.02(\mathrm{t}, J=6.6 \mathrm{~Hz}, 2 \mathrm{H}), 1.87-1.75(\mathrm{~m}$, $2 \mathrm{H}), 1.47(\mathrm{dt}, J=14.6,6.7 \mathrm{~Hz}, 2 \mathrm{H}), 1.40-1.23(\mathrm{~m}, 6 \mathrm{H}), 0.89(\mathrm{t}, J=$ $6.9 \mathrm{~Hz}, 3 \mathrm{H})$.

(8) $(n=8)$ yield: $47 \% .{ }^{1} \mathrm{H}$ NMR $\left(400 \mathrm{MHz}, \mathrm{CDCl}_{3}\right) \delta / \mathrm{ppm} 7.88-$ $7.78(\mathrm{~m}, 4 \mathrm{H}), 7.01-6.95(\mathrm{~m}, 2 \mathrm{H}), 6.95-6.88(\mathrm{~m}, 2 \mathrm{H}), 5.04(\mathrm{~s}, 1 \mathrm{H})$, $4.02(\mathrm{t}, J=6.6 \mathrm{~Hz}, 2 \mathrm{H}), 1.86-1.74(\mathrm{~m}, 2 \mathrm{H}), 1.51-1.41(\mathrm{~m}, 2 \mathrm{H})$, 1.41-1.22 (m, 8H), $0.88(\mathrm{t}, J=6.9 \mathrm{~Hz}, 3 \mathrm{H})$.

(9) $(n=12)$ yield: $\left.73.5 \% .400 \mathrm{MHz}, \mathrm{CDCl}_{3}\right) \delta / \mathrm{ppm} 7.87-7.79$ (m, 2H), 7.00-6.96 (m, 1H), 6.95-6.91 (m, 1H), $4.02(\mathrm{t}, J=6.6 \mathrm{~Hz}$, $1 \mathrm{H}), 1.85-1.76(\mathrm{~m}, 1 \mathrm{H}), 1.46(\mathrm{dd}, J=15.4,7.0 \mathrm{~Hz}, 1 \mathrm{H}), 1.26(\mathrm{~s}$, $9 \mathrm{H}), 0.87(\mathrm{t}, J=6.9 \mathrm{~Hz}, 2 \mathrm{H})$.

3.1.4 General synthetic procedure for $\mathrm{N}$-[4-(bromohexyloxy) phenyl]- $N$-(alkyloxyphenyl)diazenes, 10-12. To $250 \mathrm{~mL}$ a roundbottom flask containing 4-[(4'-alkyloxyphenyl)diazenyl]phenols, 7-9 (1.0 equiv.) in dry acetone, 1,6-dibromohexane (7.0 equiv.), anhydrous potassium carbonate (3.0 equiv.) and a catalytic amount of potassium iodide were added. The reaction mixture was refluxed for $7 \mathrm{~h}$. The reaction progress was monitored by TLC. After completion of the reaction, excess solvent was removed using a rotatory evaporator, upon which a yellow precipitate was formed. The crude product was washed with distilled water to remove excess potassium carbonate and the residue was filtered and dried. Excess 1,6-dibromohexane was removed by washing the residue with $n$-hexane and the products were recrystallized from methanol to yield compounds 10-12.

(10) $(n=7)$ yield: ${ }^{1} \mathrm{H}$ NMR $\left(400 \mathrm{MHz}, \mathrm{CDCl}_{3}\right) \delta / \mathrm{ppm} 7.89-7.81$ $(\mathrm{m}, 4 \mathrm{H}), 7.01-6.94(\mathrm{~m}, 4 \mathrm{H}), 4.03(\mathrm{td}, J=6.5,3.9 \mathrm{~Hz}, 4 \mathrm{H}), 3.43(\mathrm{t}, J$ $=6.8 \mathrm{~Hz}, 2 \mathrm{H}), 1.95-1.85(\mathrm{~m}, 3 \mathrm{H}), 1.86-1.75(\mathrm{~m}, 4 \mathrm{H}), 1.50-1.41$ (m, 2H), 1.33 (ddd, $J=11.3,10.4,5.2 \mathrm{~Hz}, 6 \mathrm{H}), 0.89$ (dd, $J=9.0$, $4.8 \mathrm{~Hz}, 3 \mathrm{H})$.

(11) $(n=8)$ yield: $77.5 \% .{ }^{1} \mathrm{H}$ NMR $\left(400 \mathrm{MHz}, \mathrm{CDCl}_{3}\right) \delta / \mathrm{ppm}$ 7.88-7.82 (m, 4H), 6.98 (dd, $J=9.0,1.0 \mathrm{~Hz}, 4 \mathrm{H}), 4.02(\mathrm{td}, J=6.5$, 
$4.5 \mathrm{~Hz}, 4 \mathrm{H}), 3.42(\mathrm{q}, J=6.4 \mathrm{~Hz}, 2 \mathrm{H}), 1.90(\mathrm{dd}, J=13.9,7.0 \mathrm{~Hz}$, $2 \mathrm{H}), 1.86-1.71(\mathrm{~m}, 4 \mathrm{H}), 1.51$ (dd, $J=9.8,6.2 \mathrm{~Hz}, 3 \mathrm{H}), 1.48-1.40$ $(\mathrm{m}, 2 \mathrm{H}), 1.26(\mathrm{~s}, 16 \mathrm{H}), 0.87(\mathrm{t}, J=6.8 \mathrm{~Hz}, 3 \mathrm{H})$.

(12) $(n=12)$ yield: $50 \% .{ }^{1} \mathrm{H}$ NMR $\left(400 \mathrm{MHz}, \mathrm{CDCl}_{3}\right) \delta / \mathrm{ppm}$ 7.88-7.82 (m, $4 \mathrm{H}), 6.98(\mathrm{dd}, J=9.0,1.0 \mathrm{~Hz}, 4 \mathrm{H}), 4.02(\mathrm{td}, J=6.5$, $4.5 \mathrm{~Hz}, 4 \mathrm{H}), 3.42(\mathrm{q}, J=6.4 \mathrm{~Hz}, 2 \mathrm{H}), 1.90(\mathrm{dd}, J=13.9,7.0 \mathrm{~Hz}$, $2 \mathrm{H}), 1.86-1.71(\mathrm{~m}, 4 \mathrm{H}), 1.51$ (dd, $J=9.8,6.2 \mathrm{~Hz}, 3 \mathrm{H}), 1.48-1.40$ $(\mathrm{m}, 2 \mathrm{H}), 1.26(\mathrm{~s}, 16 \mathrm{H}), 0.87(\mathrm{t}, J=6.8 \mathrm{~Hz}, 3 \mathrm{H})$.

3.1.5 General synthetic procedure for $\mathrm{N}, \mathrm{N}$-diethanol-6-(4((4'-alkyloxyphenyl)diazinyl)phenoxy)hexan-1-amines, 13-15. To a $250 \mathrm{~mL}$ round-bottom flask containing the corresponding $\mathrm{N}$-[4-(bromohexyloxy)phenyl]- $N$-(alkyloxyphenyl)diazenes, 1012, in 2-propanol, $N, N$-diethanol amine was added in excess. The reaction mixture was refluxed for $38 \mathrm{~h}$. The reaction progress was monitored by TLC. After completion of the reaction, excess solvent was removed using a rotatory evaporator. The crude products were recrystallized from ethanol to yield compounds 13-15.

(13) $(n=7)$ yield: $73.02 \% .{ }^{1} \mathrm{H}$ NMR $\left(400 \mathrm{MHz}, \mathrm{CDCl}_{3}\right) \delta / \mathrm{ppm}$ $7.87-7.81(\mathrm{~m}, 4 \mathrm{H}), 6.98(\mathrm{t}, J=5.9 \mathrm{~Hz}, 4 \mathrm{H}), 4.05-3.98(\mathrm{~m}, 4 \mathrm{H})$, 3.66-3.57 (m, 4H), $2.66(\mathrm{t}, J=5.4 \mathrm{~Hz}, 4 \mathrm{H}), 2.57-2.50(\mathrm{~m}, 2 \mathrm{H})$, 1.86-1.74 (m, 6H), 1.56-1.42 (m, 6H), 1.42-1.20 (m, 9H), 0.88 (q, $J=7.0 \mathrm{~Hz}, 3 \mathrm{H})$.

(14) $(n=8)$ yield: $73.8 \% .{ }^{1} \mathrm{H}$ NMR $\left(400 \mathrm{MHz}, \mathrm{CDCl}_{3}\right) \delta / \mathrm{ppm}$ 7.88-7.81 (m, 4H), $6.98(\mathrm{t}, J=6.0 \mathrm{~Hz}, 4 \mathrm{H}), 4.05-3.99(\mathrm{~m}, 4 \mathrm{H})$, $3.62(\mathrm{t}, J=5.4 \mathrm{~Hz}, 4 \mathrm{H}), 2.67(\mathrm{t}, J=5.4 \mathrm{~Hz}, 4 \mathrm{H}), 2.54(\mathrm{~d}, J=7.5 \mathrm{~Hz}$, $2 \mathrm{H}), 1.80(\mathrm{dt}, J=14.6,5.2 \mathrm{~Hz}, 5 \mathrm{H}), 1.49(\mathrm{dd}, J=13.5,6.4 \mathrm{~Hz}, 6 \mathrm{H})$, $1.41-1.23(\mathrm{~m}, 11 \mathrm{H}), 0.88(\mathrm{t}, J=6.9 \mathrm{~Hz}, 3 \mathrm{H})$.

(15) $(n=12)$ yield: $52.6 \% .{ }^{1} \mathrm{H}$ NMR $\left(400 \mathrm{MHz}, \mathrm{CDCl}_{3}\right) \delta / \mathrm{ppm}$ $7.87-7.82(\mathrm{~m}, 4 \mathrm{H}), 6.98(\mathrm{~d}, J=9.0 \mathrm{~Hz}, 4 \mathrm{H}), 4.02(\mathrm{td}, J=6.5$, $1.9 \mathrm{~Hz}, 4 \mathrm{H}), 3.62(\mathrm{td}, J=5.4,2.9 \mathrm{~Hz}, 4 \mathrm{H}), 2.66(\mathrm{dd}, J=9.8$, $4.5 \mathrm{~Hz}, 4 \mathrm{H}), 2.57-2.51(\mathrm{~m}, 2 \mathrm{H}), 1.80(\mathrm{dd}, J=16.8,9.0 \mathrm{~Hz}, 7 \mathrm{H})$, 1.55-1.41 (m, 7H), 1.36 (dd, $J=20.2,11.4 \mathrm{~Hz}, 5 \mathrm{H}), 1.26(\mathrm{~s}, 15 \mathrm{H})$, $0.86(\mathrm{~d}, J=7.0 \mathrm{~Hz}, 3 \mathrm{H})$.

3.1.6 General synthetic procedure for $\mathrm{N}$-ethyl- $\mathrm{N}$-ethanol-6(4-((4'-alkyloxyphenyl)diazenyl)phenoxy)hexan-1-amines, 1618. To a $250 \mathrm{~mL}$ round-bottom flask containing the corresponding $\quad N$-[4-(bromohexyloxy)phenyl]- $N$-(alkyloxyphenyl)diazenes, 10-12 in 2-propanol, $N$-ethyl- $N$-ethanol amine was added in excess. The reaction mixture was refluxed for $38 \mathrm{~h}$ and the reaction progress was monitored by TLC. After completion of the reaction, excess solvent was removed using a rotatory evaporator. The crude products were recrystallized from ethanol to yield compounds 16-18.

(16) $(n=7)$ yield: $64.6 \% .{ }^{1} \mathrm{H}$ NMR $\left(400 \mathrm{MHz}, \mathrm{CDCl}_{3}\right) \delta / \mathrm{ppm}$ $7.86-7.81(\mathrm{~m}, 4 \mathrm{H}), 6.98(\mathrm{dd}, J=6.9,5.0 \mathrm{~Hz}, 4 \mathrm{H}), 4.02(\mathrm{t}, J=$ $6.6 \mathrm{~Hz}, 4 \mathrm{H}), 3.55-3.51(\mathrm{~m}, 2 \mathrm{H}), 2.60-2.52(\mathrm{~m}, 4 \mathrm{H}), 2.49-2.44(\mathrm{~m}$, $2 \mathrm{H}), 1.85-1.77(\mathrm{~m}, 4 \mathrm{H}), 1.53-1.41(\mathrm{~m}, 7 \mathrm{H}), 1.42-1.25(\mathrm{~m}, 10 \mathrm{H})$, 1.04-0.99 (m, 3H), 0.90-0.85 (m, 3H).

(17) $(n=8)$ yield: $52.9 \% .{ }^{1} \mathrm{H}$ NMR $\left(400 \mathrm{MHz}, \mathrm{CDCl}_{3}\right) \delta / \mathrm{ppm}$ $7.84(\mathrm{t}, J=9.0 \mathrm{~Hz}, 4 \mathrm{H}), 6.96(\mathrm{t}, J=9.0 \mathrm{~Hz}, 4 \mathrm{H}), 4.02(\mathrm{t}, J=6.2 \mathrm{~Hz}$, $4 \mathrm{H}), 3.53(\mathrm{t}, J=5.4 \mathrm{~Hz}, 2 \mathrm{H}), 2.61-2.51(\mathrm{~m}, 4 \mathrm{H}), 2.49-2.43(\mathrm{~m}$, $2 \mathrm{H}), 1.86-1.76(\mathrm{~m}, 4 \mathrm{H}), 1.54-1.42(\mathrm{~m}, 6 \mathrm{H}), 1.41-1.23(\mathrm{~m}, 10 \mathrm{H})$, $1.01(\mathrm{t}, J=7.1 \mathrm{~Hz}, 3 \mathrm{H}), 0.88(\mathrm{t}, J=6.8 \mathrm{~Hz}, 3 \mathrm{H})$.

(18) $(n=9)$ yield: $61.3 \% .{ }^{1} \mathrm{H}$ NMR $(400 \mathrm{MHz}$, CHLOROFORMD) $\delta 7.88-7.82(\mathrm{~m}, 15 \mathrm{H}), 7.01-6.95(\mathrm{~m}, 15 \mathrm{H}), 4.06-3.99(\mathrm{~m}, 15 \mathrm{H})$, $3.53(\mathrm{t}, J=5.4 \mathrm{~Hz}, 8 \mathrm{H}), 2.60-2.52(\mathrm{~m}, 17 \mathrm{H}), 2.49-2.44(\mathrm{~m}, 8 \mathrm{H})$, $1.81(\mathrm{dd}, J=13.2,6.1 \mathrm{~Hz}, 16 \mathrm{H}), 1.53-1.42(\mathrm{~m}, 26 \mathrm{H}), 1.42-1.33(\mathrm{~m}$, $17 \mathrm{H}), 1.26(\mathrm{~s}, 52 \mathrm{H}), 1.05-0.98(\mathrm{~m}, 11 \mathrm{H}), 0.87(\mathrm{t}, J=6.9 \mathrm{~Hz}, 11 \mathrm{H})$.

3.1.7 N,N-diethyl-6-(4-((4'-alkyloxyphenyl)diazenyl)phenoxy) hexan-1-amines, 19-21. To a $250 \mathrm{~mL}$ round-bottom flask containing the corresponding $N$-[4-(bromohexyloxy)phenyl]- $N$-(alkyloxyphenyl)diazenes, 10-12, in 2-propanol, $N, N$-diethyl amine was added in excess. The reaction mixture was refluxed for $38 \mathrm{~h}$ and the reaction progress was monitored by TLC. After completion of the reaction, excess solvent was removed using a rotatory evaporator. The crude products were recrystallized from ethanol to yield compounds 19-21.

(19) $(n=7)$ yield: $60 \% .{ }^{1} \mathrm{H}$ NMR $\left(400 \mathrm{MHz}, \mathrm{CDCl}_{3}\right) \delta / \mathrm{ppm}$ 7.88-7.82 (m, 4H), 7.00-6.95 (m, 4H), $4.02(\mathrm{t}, J=6.5 \mathrm{~Hz}, 4 \mathrm{H})$, $2.53(\mathrm{q}, J=7.1 \mathrm{~Hz}, 4 \mathrm{H}), 2.46-2.40(\mathrm{~m}, 2 \mathrm{H}), 1.80(\mathrm{dt}, J=14.9$, $5.5 \mathrm{~Hz}, 4 \mathrm{H}), 1.49$ (dd, $J=12.9,5.5 \mathrm{~Hz}, 7 \mathrm{H}), 1.41-1.27$ (m, 9H), $1.02(\mathrm{t}, J=7.2 \mathrm{~Hz}, 6 \mathrm{H}), 0.89(\mathrm{t}, J=6.9 \mathrm{~Hz}, 3 \mathrm{H})$.

(20) $(n=8)$ yield: 93.5\%. 7.86-7.82 (m, 4H), 7.00-6.93 (m, $4 \mathrm{H}), 4.01(\mathrm{t}, J=6.5 \mathrm{~Hz}, 4 \mathrm{H}), 2.52$ (q, $J=7.1 \mathrm{~Hz}, 4 \mathrm{H}), 2.44-2.40$ $(\mathrm{m}, 2 \mathrm{H}), 1.78(\mathrm{dt}, J=14.9,5.5 \mathrm{~Hz}, 4 \mathrm{H}), 1.47(\mathrm{dd}, J=12.9,5.5 \mathrm{~Hz}$, $10 \mathrm{H}), 1.41-1.27(\mathrm{~m}, 10 \mathrm{H}), 1.02(\mathrm{t}, J=7.2 \mathrm{~Hz}, 6 \mathrm{H}), 0.89(\mathrm{t}, J=$ $6.9 \mathrm{~Hz}, 3 \mathrm{H})$.

(21) $(n=12)$ yield: $85.71 \% .{ }^{1} \mathrm{H}$ NMR $\left(400 \mathrm{MHz}, \mathrm{CDCl}_{3}\right) \delta / \mathrm{ppm}$ $7.85(\mathrm{~d}, J=8.9 \mathrm{~Hz}, 4 \mathrm{H}), 6.97(\mathrm{~d}, J=9.1 \mathrm{~Hz}, 4 \mathrm{H}), 4.02(\mathrm{t}, J=$ $5.9 \mathrm{~Hz}, 4 \mathrm{H}), 2.52$ (dd, $J=14.4,7.2 \mathrm{~Hz}, 4 \mathrm{H}), 2.45-2.39(\mathrm{~m}, 2 \mathrm{H})$, 1.81 (dd, $J=13.6,7.0 \mathrm{~Hz}, 5 \mathrm{H}), 1.53-1.43(\mathrm{~m}, 7 \mathrm{H}), 1.31$ (d, $J=$ $40.8 \mathrm{~Hz}, 20 \mathrm{H}), 1.02(\mathrm{t}, J=7.2 \mathrm{~Hz}, 6 \mathrm{H}), 0.87(\mathrm{t}, J=6.7 \mathrm{~Hz}, 3 \mathrm{H})$.

3.1.8 $N$, $N$-diethanol-6-(4-(( $4^{\prime}$-alkyloxyphenyl)diazenyl)phenoxy)hexan-1-ammonium iodides, 22-24. To a $250 \mathrm{~mL}$ roundbottom flask containing the corresponding $N, N$-diethanol-6-(4((4'-alkyloxyphenyl)diazinyl)phenoxy)hexan-1-amines in acetonitrile, 13-15, excess ethyl iodide was added. The reaction mixture was refluxed for $36 \mathrm{~h}$ and the reaction progress was monitored by TLC. After completion of the reaction, excess solvent was removed using a rotatory evaporator. The crude product was recrystalized from a mixture of ethanol $/ n$-hexane to yield compounds 22-24.

(22) $(n=7)$ yield: $30.8 \%$. Elemental analysis: calculated for $\mathrm{C}_{31} \mathrm{H}_{50} \mathrm{IN}_{3} \mathrm{O}_{4}: \mathrm{C}=56.79, \mathrm{H}=7.69, \mathrm{~N}=6.41$; found: $\mathrm{C}=56.184$, $\mathrm{H}=7.601, \mathrm{~N}=6.327$. HRMS $\left[\mathrm{C}_{31} \mathrm{H}_{50} \mathrm{~N}_{3} \mathrm{O}_{4}\right]^{+}=528.3802 .{ }^{1} \mathrm{H}$ NMR (400 MHz, $\mathrm{CDCl}_{3}$ ) $\delta / \mathrm{ppm} 7.86-7.81$ (m, 16H), 6.97 (ddd, $J$ $=6.9,5.0,2.6 \mathrm{~Hz}, 16 \mathrm{H}), 4.10(\mathrm{~s}, 16 \mathrm{H}), 4.05-3.98(\mathrm{~m}, 25 \mathrm{H}), 3.68-$ $3.63(\mathrm{~m}, 15 \mathrm{H}), 3.57$ (q, $J=7.1 \mathrm{~Hz}, 8 \mathrm{H}), 3.48-3.41(\mathrm{~m}, 8 \mathrm{H}), 1.80$ (dt, $J=8.0,6.5 \mathrm{~Hz}, 17 \mathrm{H}), 1.60-1.51(\mathrm{~m}, 10 \mathrm{H}), 1.50-1.39(\mathrm{~m}$, 18H), 1.39-1.25 (m, 40H), 0.90-0.86 (m, 12H). ${ }^{13} \mathrm{C}$ NMR (101 $\mathrm{MHz}, \mathrm{CDCl}_{3}$ ) $\delta / \mathrm{ppm} 161.34,161.07,146.94,124.74$ (d, $J=8.0$ $\mathrm{Hz}), 124.41,124.04,123.71,115.06-114.54,114.40$ (d, $J=8.1$ $\mathrm{Hz}), 110.98$ (d, $J=1.4 \mathrm{~Hz}), 103.65(\mathrm{~s}), 89.59$ (d, $J=3.2 \mathrm{~Hz}), 83.33$ $(\mathrm{d}, J=12.1 \mathrm{~Hz}), 82.92(\mathrm{~s}), 82.53(\mathrm{~s}), 82.15(\mathrm{~s}), 82.03-81.83,81.60$, 81.37-81.16, 80.95 (dd, $J=14.1,9.8 \mathrm{~Hz}$ ), 80.71, 80.24 (d, $J=7.7$ $\mathrm{Hz}$ ), 79.85 (dd, $J=16.6,7.4 \mathrm{~Hz}), 79.09$ (s), 78.86-77.71 (m), $77.73-77.71(\mathrm{~m}), 77.38(\mathrm{~d}, J=11.9 \mathrm{~Hz}), 77.12,76.41(\mathrm{~d}, J=77.7$ $\mathrm{Hz}), 75.09$ (d, $J=17.3 \mathrm{~Hz}), 74.72,74.61-74.09,73.87-73.45$, $73.30(\mathrm{~d}, J=6.8 \mathrm{~Hz}), 72.84(\mathrm{~s}), 71.45(\mathrm{~s}), 68.48(\mathrm{~d}, J=10.6 \mathrm{~Hz})$, $67.97(\mathrm{~d}, J=13.3 \mathrm{~Hz}), 66.34(\mathrm{~s}), 65.04(\mathrm{~d}, J=14.4 \mathrm{~Hz}), 60.69$ (d, $J$ $=7.2 \mathrm{~Hz}), 59.93(\mathrm{~s}), 56.00(\mathrm{~s}), 55.53(\mathrm{~d}, J=17.3 \mathrm{~Hz}), 53.69-53.28$, 41.42 (d, $J=1.4 \mathrm{~Hz}), 40.45$ (d, $J=5.3 \mathrm{~Hz}), 39.54-39.25,32.31-$ $31.75,31.12$ (d, $J=19.6 \mathrm{~Hz}$ ), 29.75, 29.50-28.77, 26.37-25.47, 
24.73, 22.85-22.45, 21.88 (d, $J=52.8 \mathrm{~Hz}), 14.56,14.17,8.41(\mathrm{~d}, J$ $=11.6 \mathrm{~Hz}), 4.12(\mathrm{dd}, J=28.5,9.0 \mathrm{~Hz}),-20.92$ to -21.26 .

(23) $(n=8)$ yield: $40.0 \%$. Elemental analysis: calculated for $\mathrm{C}_{32} \mathrm{H}_{52} \mathrm{IN}_{3} \mathrm{O}_{4}: \mathrm{C}=57.39, \mathrm{H}=7.83, \mathrm{~N}=6.27$; found: $\mathrm{C}=57.019$, $\mathrm{H}=7.707, \mathrm{~N}=6.175$. HRMS $\left[\mathrm{C}_{32} \mathrm{H}_{52} \mathrm{~N}_{3} \mathrm{O}_{4}\right]^{+}=542.3959 .{ }^{1} \mathrm{H}$ NMR (400 MHz, $\mathrm{CDCl}_{3}$ ) $\delta / \mathrm{ppm} 7.84(\mathrm{~d}, J=8.9 \mathrm{~Hz}, 6 \mathrm{H}), 7.00-6.94$ (m, 6H), 4.10 (s, 8H), 4.01 (q, $J=6.5 \mathrm{~Hz}, 6 \mathrm{H}), 3.66(\mathrm{~s}, 6 \mathrm{H}), 3.57$ $(\mathrm{dd}, J=14.2,6.9 \mathrm{~Hz}, 3 \mathrm{H}), 3.48-3.41(\mathrm{~m}, 4 \mathrm{H}), 1.80(\mathrm{dd}, J=14.2$, $7.1 \mathrm{~Hz}, 6 \mathrm{H}), 1.76-1.70(\mathrm{~m}, 4 \mathrm{H}), 1.55$ (d, $J=7.2 \mathrm{~Hz}, 4 \mathrm{H}), 1.45$ (d, $=7.2 \mathrm{~Hz}, 7 \mathrm{H}), 1.32(\mathrm{dd}, J=18.5,11.3 \mathrm{~Hz}, 17 \mathrm{H}), 0.87(\mathrm{dd}, J=9.2$, $4.5 \mathrm{~Hz}, 4 \mathrm{H}) .{ }^{13} \mathrm{C} \mathrm{NMR}\left(101 \mathrm{MHz}, \mathrm{CDCl}_{3}\right) \delta / \mathrm{ppm} 161.35$ (s), 161.08 (s), 146.93 (d, $J=13.1 \mathrm{~Hz}), 124.42(\mathrm{~s}), 114.82(\mathrm{~d}, J=11.1 \mathrm{~Hz})$, 77.45 (s), 77.13 (s), 76.81 (s), 68.43 (s), 68.04 (s), 60.64 (s), 59.94 (s), $56.00(\mathrm{~s}), 55.60(\mathrm{~s}), 31.90(\mathrm{~s}), 29.55-29.20(\mathrm{~m}), 29.03(\mathrm{~s}), 26.10$ (s), 25.67 (s), 22.69 (d, $J=10.1 \mathrm{~Hz}$ ), 22.15 (s), 14.20 (s), 8.49 (s).

(24) $(n=12)$ yield: $36.8 \%$. Elemental analysis: calculated for $\mathrm{C}_{36} \mathrm{H}_{60} \mathrm{IN}_{3} \mathrm{O}_{4}: \mathrm{C}=59.58, \mathrm{H}=8.33, \mathrm{~N}=5.79$; found: $\mathrm{C}=59.39, \mathrm{H}$ $=8.25, \mathrm{~N}=5.709$. HRMS $\left[\mathrm{C}_{36} \mathrm{H}_{60} \mathrm{~N}_{3} \mathrm{O}_{4}\right]^{+}=598.4585 .{ }^{1} \mathrm{H} \mathrm{NMR}$ $\left(400 \mathrm{MHz}, \mathrm{CDCl}_{3}\right) \delta / \mathrm{ppm} 7.84(\mathrm{dd}, J=9.0,0.7 \mathrm{~Hz}, 16 \mathrm{H}), 7.00-$ $6.94(\mathrm{~m}, 16 \mathrm{H}), 4.11(\mathrm{~s}, 16 \mathrm{H}), 4.01(\mathrm{dd}, J=14.2,6.5 \mathrm{~Hz}, 20 \mathrm{H}), 3.67$ $(\mathrm{d}, J=3.1 \mathrm{~Hz}, 15 \mathrm{H}), 3.58(\mathrm{q}, J=7.2 \mathrm{~Hz}, 8 \mathrm{H}), 3.49-3.42(\mathrm{~m}, 8 \mathrm{H})$, $1.86-1.76(\mathrm{~m}, 17 \mathrm{H}), 1.72(\mathrm{dd}, J=16.3,9.4 \mathrm{~Hz}, 10 \mathrm{H}), 1.45(\mathrm{dt}, J=$ 14.1, 7.2 Hz, 19H), 1.34 (t, $J=7.2 \mathrm{~Hz}, 25 \mathrm{H}), 1.27$ (d, $J=13.8 \mathrm{~Hz}$, $57 \mathrm{H}), 0.87(\mathrm{t}, J=6.9 \mathrm{~Hz}, 12 \mathrm{H}) .{ }^{13} \mathrm{C}$ NMR $\left(101 \mathrm{MHz}, \mathrm{CDCl}_{3}\right) \delta /$ ppm 161.35, 161.05, 146.97 (d, $J=14.8 \mathrm{~Hz}), 124.4,114.81(\mathrm{~d}, J=$ $9.0 \mathrm{~Hz}), 77.43,77.11,76.79$, 68.43, 67.98, 60.69, 59.96, 55.97, $55.68,53.52,32.00,31.02,29.86-29.17,29.02,26.11,25.69$, $22.77,22.15,14.21,8.39$.

3.1.9 $N$-ethyl- $N$-ethanol-6-(4-((4'-alkyloxyphenyl)diazenyl) phenoxy)hexan-1-ammonium iodides, 25-27. Compounds 2517 were synthesized following the procedure described for the preparation of compounds 22-24, using the corresponding $N$ ethyl- $N$-ethanol-6-(4-(( $4^{\prime}$-alkyloxyphenyl)diazenyl)phenoxy) hexan-1-amines 16-18 as the starting materials.

(25) $(n=7)$ yield: $60.0 \%$. Elemental analysis: calculated for $\mathrm{C}_{31} \mathrm{H}_{50} \mathrm{IN}_{3} \mathrm{O}_{3}: \mathrm{C}=58.21, \mathrm{H}=7.88, \mathrm{~N}=6.57$; found: $\mathrm{C}=57.724, \mathrm{H}$ $=7.802, \mathrm{~N}=6.302$. HRMS $\left[\mathrm{C}_{31} \mathrm{H}_{50} \mathrm{~N}_{3} \mathrm{O}_{3}\right]^{+}=512.3839 .{ }^{1} \mathrm{H} \mathrm{NMR}$ $\left(400 \mathrm{MHz}, \mathrm{CDCl}_{3}\right) \delta /$ ppm $7.84(\mathrm{dd}, J=9.0,0.7 \mathrm{~Hz}, 4 \mathrm{H}), 7.01-6.94$ $(\mathrm{m}, 4 \mathrm{H}), 4.36(\mathrm{t}, J=6.0 \mathrm{~Hz}, 1 \mathrm{H}), 4.12(\mathrm{~s}, 2 \mathrm{H}), 4.02(\mathrm{dt}, J=9.4$, $6.4 \mathrm{~Hz}, 4 \mathrm{H}), 3.58-3.47(\mathrm{~m}, 6 \mathrm{H}), 3.43-3.36(\mathrm{~m}, 2 \mathrm{H}), 1.88-1.70(\mathrm{~m}$, $6 \mathrm{H}), 1.63-1.53(\mathrm{~m}, 4 \mathrm{H}), 1.47(\mathrm{td}, J=14.3,7.1 \mathrm{~Hz}, 4 \mathrm{H}), 1.36(\mathrm{t}, J=$ $7.1 \mathrm{~Hz}, 7 \mathrm{H}), 1.33-1.27(\mathrm{~m}, 4 \mathrm{H}), 0.89(\mathrm{t}, J=6.9 \mathrm{~Hz}, 3 \mathrm{H}) .{ }^{13} \mathrm{C} \mathrm{NMR}$ (101 MHz, $\mathrm{CDCl}_{3}$ ) $\delta / \mathrm{ppm} \mathrm{161.34,} \mathrm{161.06,} 146.96(\mathrm{~d}, J=12.7 \mathrm{~Hz}$ ), 124.40, 114.81 (d, $J=7.5 \mathrm{~Hz}$ ), 100.00, 77.48, 77.16, 76.84, 75.37, 68.43, 67.97, 59.56, 58.88, 55.35, 54.80, 31.85, $29.15(\mathrm{t}, J=13.9 \mathrm{~Hz})$, $26.12(\mathrm{~d}, J=12.5 \mathrm{~Hz}), 25.70,22.64(\mathrm{~d}, J=7.9 \mathrm{~Hz}), 22.21,14.17,8.37$.

(26) $(n=8)$ yield: $62.5 \%$. Elemental analysis: calculated for $\mathrm{C}_{31} \mathrm{H}_{50} \mathrm{IN}_{3} \mathrm{O}_{4}: \mathrm{C}=58.80, \mathrm{H}=8.02, \mathrm{~N}=6.43$; found: $\mathrm{C}=58.435$, $\mathrm{H}=7.919, \mathrm{~N}=6.287$. HRMS $\left[\mathrm{C}_{32} \mathrm{H}_{52} \mathrm{~N}_{3} \mathrm{O}_{3}\right]^{+}=526.4027$. Yield: ${ }^{1} \mathrm{H}$ NMR (400 MHz, $\mathrm{CDCl}_{3}$ ) $\delta / \mathrm{ppm} 7.84$ (d, $\left.J=8.7 \mathrm{~Hz}, 4 \mathrm{H}\right), 6.97$ $(\mathrm{dd}, J=9.0,2.2 \mathrm{~Hz}, 4 \mathrm{H}), 4.36(\mathrm{t}, J=6.0 \mathrm{~Hz}, 1 \mathrm{H}), 4.12(\mathrm{~s}, 2 \mathrm{H}), 4.02$ $(\mathrm{dt}, J=9.6,6.4 \mathrm{~Hz}, 4 \mathrm{H}), 3.55(\mathrm{~d}, J=8.7 \mathrm{~Hz}, 2 \mathrm{H}), 3.53-3.45(\mathrm{~m}$, $3 \mathrm{H}), 3.43-3.34(\mathrm{~m}, 2 \mathrm{H}), 1.89-1.68(\mathrm{~m}, 6 \mathrm{H}), 1.60-1.53(\mathrm{~m}, 2 \mathrm{H})$, 1.53-1.41 (m, 4H), 1.35 (t, $J=7.2 \mathrm{~Hz}, 7 \mathrm{H}), 1.29$ (d, $J=9.4 \mathrm{~Hz}$, $5 \mathrm{H}), 0.88(\mathrm{t}, J=6.8 \mathrm{~Hz}, 3 \mathrm{H}) .{ }^{13} \mathrm{C} \mathrm{NMR}\left(101 \mathrm{MHz}, \mathrm{CDCl}_{3}\right) \delta / \mathrm{ppm}$ $161.35(\mathrm{~d}, J=2.4 \mathrm{~Hz}), 161.07(\mathrm{~s}), 146.92$ (d, $J=11.9 \mathrm{~Hz}), 124.72-$ 124.08, 122.78 (d, $J=14.1 \mathrm{~Hz}), 114.66(\mathrm{dd}, J=29.2,10.1 \mathrm{~Hz})$,
77.47 (d, $J=11.1 \mathrm{~Hz}), 77.21,76.89,68.43,68.00,59.51,58.85$, $55.33,54.81,32.01-31.67,29.55-29.18,29.01,26.35-25.94$, 25.67, 22.87-22.57 (m), 22.19, 14.18, 8.41.

(27) $(n=12)$ yield: $20.8 \%$. Elemental analysis: calculated for $\mathrm{C}_{36} \mathrm{H}_{60} \mathrm{IN}_{3} \mathrm{O}_{3}: \mathrm{C}=60.92, \mathrm{H}=8.52, \mathrm{~N}=5.92$; found: $\mathrm{C}=58.221$, $\mathrm{H}=$ 8.095, $\mathrm{N}=$ 5.558. HRMS $\left[\mathrm{C}_{36} \mathrm{H}_{60} \mathrm{~N}_{3} \mathrm{O}_{3}\right]^{+}=582.4630 .{ }^{1} \mathrm{H}$ NMR (400 MHz, $\mathrm{CDCl}_{3}$ ) $\delta / \mathrm{ppm} 7.84(\mathrm{dd}, J=8.9,0.7 \mathrm{~Hz}, 9 \mathrm{H})$, 7.00-6.94 (m, 9H), $4.26(\mathrm{t}, J=5.8 \mathrm{~Hz}, 2 \mathrm{H}), 4.14(\mathrm{~s}, 4 \mathrm{H}), 4.03(\mathrm{tt}, J$ $=11.3,5.9 \mathrm{~Hz}, 10 \mathrm{H}), 3.58-3.45(\mathrm{~m}, 12 \mathrm{H}), 3.42-3.34(\mathrm{~m}, 4 \mathrm{H})$, $1.87-1.69(\mathrm{~m}, 14 \mathrm{H}), 1.53-1.40(\mathrm{~m}, 12 \mathrm{H}), 1.35(\mathrm{t}, J=7.2 \mathrm{~Hz}, 17 \mathrm{H})$, $1.32-1.19(\mathrm{~m}, 36 \mathrm{H}), 0.86(\mathrm{t}, J=6.8 \mathrm{~Hz}, 7 \mathrm{H})$.

\subsubsection{N,N-diethyl-6-(4-((4'-alkyloxyphenyl)diazenyl)}

phenoxy)hexan-1-ammonium iodides, 28-30. Compounds 2830 were synthesized following the procedure described for the preparation of compounds 22-24 using the corresponding $\mathrm{N}, \mathrm{N}$ diethyl-6-(4-((4'-alkyloxyphenyl)diazenyl)phenoxy)hexan-1-

amines 19-21 as the starting materials.

(28) $(n=7)$ yield: $15.0 \%$. Elemental analysis: calculated for $\mathrm{C}_{31} \mathrm{H}_{50} \mathrm{IN}_{3} \mathrm{O}_{2}: \mathrm{C}=59.70, \mathrm{H}=8.08, \mathrm{~N}=6.74$; found: $\mathrm{C}=58.677$, $\mathrm{H}=7.889, \mathrm{~N}=6.432$. HRMS $\left[\mathrm{C}_{31} \mathrm{H}_{50} \mathrm{~N}_{3} \mathrm{O}_{2}\right]^{+}=496.3918 .{ }^{1} \mathrm{H}$ NMR (400 MHz, $\mathrm{CDCl}_{3}$ ) $\delta / \mathrm{ppm} 7.85(\mathrm{~d}, J=8.8 \mathrm{~Hz}, 7 \mathrm{H}), 6.97$ (d, $J$ $=8.9 \mathrm{~Hz}, 7 \mathrm{H}), 4.08-3.99(\mathrm{~m}, 7 \mathrm{H}), 3.45(\mathrm{q}, J=7.3 \mathrm{~Hz}, 10 \mathrm{H}), 3.33-$ $3.27(\mathrm{~m}, 4 \mathrm{H}), 1.89-1.71(\mathrm{~m}, 11 \mathrm{H}), 1.59(\mathrm{~s}, 19 \mathrm{H}), 1.55-1.49(\mathrm{~m}$, $4 \mathrm{H}), 1.45$ (dd, $J=15.3,7.5 \mathrm{~Hz}, 4 \mathrm{H}), 1.39$ (t, $J=7.2 \mathrm{~Hz}, 16 \mathrm{H}), 1.31$ $(\mathrm{s}, 7 \mathrm{H}), 0.89$ (t, $J=6.9 \mathrm{~Hz}, 5 \mathrm{H}) .{ }^{13} \mathrm{C} \mathrm{NMR}\left(101 \mathrm{MHz}, \mathrm{CDCl}_{3}\right) \delta /$ ppm 161.34 (s), 161.03 (s), 146.99 (d, $J=13.7 \mathrm{~Hz}), 124.41$ (s), 114.80 (d, $J=5.7 \mathrm{~Hz}$ ), 77.45 (s), 77.13 (s), 76.81 (s), 68.44 (s), $67.94(\mathrm{~s}), 53.91(\mathrm{~s}), 31.85(\mathrm{~s}), 29.39-28.87(\mathrm{~m}), 26.29(\mathrm{~s}), 26.06(\mathrm{~s})$, 25.77 (s), 22.65 (d, J=7.1 Hz), 22.31 (s), 14.18 (s), $8.44(\mathrm{~s})$.

(29) $(n=8)$ yield: $48.0 \%$. Elemental analysis: calculated for $\mathrm{C}_{32} \mathrm{H}_{52} \mathrm{IN}_{3} \mathrm{O}_{2}: \mathrm{C}=60.27, \mathrm{H}=8.22, \mathrm{~N}=6.59$; found: $\mathrm{C}=59.338$, $\mathrm{H}=8.039, \mathrm{~N}=6.273$. HRMS $\left[\mathrm{C}_{32} \mathrm{H}_{52} \mathrm{~N}_{3} \mathrm{O}_{2}\right]^{+}=510.4064 .{ }^{1} \mathrm{H}$ NMR (400 MHz, $\mathrm{CDCl}_{3}$ ) $\delta / \mathrm{ppm} 7.84$ (d, $\left.J=8.5 \mathrm{~Hz}, 8 \mathrm{H}\right), 6.97$ (dd, $J=9.0,1.3 \mathrm{~Hz}, 8 \mathrm{H}), 4.02(\mathrm{dt}, J=13.0,6.4 \mathrm{~Hz}, 8 \mathrm{H}), 3.44(\mathrm{q}, J=$ $7.3 \mathrm{~Hz}, 11 \mathrm{H}), 3.33-3.26$ (m, 4H), 1.88-1.71 (m, 12H), 1.70-1.55 $(\mathrm{m}, 13 \mathrm{H}), 1.55-1.41(\mathrm{~m}, 9 \mathrm{H}), 1.38(\mathrm{t}, J=7.2 \mathrm{~Hz}, 17 \mathrm{H}), 1.30(\mathrm{dt}, J$ $=16.8,10.5 \mathrm{~Hz}, 14 \mathrm{H}), 0.88(\mathrm{dd}, J=8.6,5.2 \mathrm{~Hz}, 6 \mathrm{H}) .{ }^{13} \mathrm{C} \mathrm{NMR}$ $\left(101 \mathrm{MHz}, \mathrm{CDCl}_{3}\right) \delta /$ ppm 161.33, 161.03, $146.97(\mathrm{~d}, J=12.8 \mathrm{~Hz})$, 124.39, $114.80(\mathrm{~d}, J=5.8 \mathrm{~Hz}), 77.47,77.15,76.83,68.44,67.95$, $57.81,53.88,31.88,29.37$ (d, $J=12.8 \mathrm{~Hz}), 29.01,26.19$ (d, $J=$ $17.3 \mathrm{~Hz}), 25.75,22.73,22.30,14.19,8.43$.

(30) $(n=12)$ yield: $43.2 \%$. Elemental analysis: calculated for $\mathrm{C}_{36} \mathrm{H}_{60} \mathrm{IN}_{3} \mathrm{O}_{2}: \mathrm{C}=62.32, \mathrm{H}=8.72, \mathrm{~N}=6.06$; found: $\mathrm{C}=61.73, \mathrm{H}$ $=8.617, \mathrm{~N}=5.913$. HRMS $\left[\mathrm{C}_{36} \mathrm{H}_{60} \mathrm{~N}_{3} \mathrm{O}_{2}\right]^{+}=566.4680 .{ }^{1} \mathrm{H} \mathrm{NMR}$ $\left(400 \mathrm{MHz}, \mathrm{CDCl}_{3}\right) \delta / \mathrm{ppm} 7.84(\mathrm{~d}, J=8.6 \mathrm{~Hz}, 4 \mathrm{H}), 6.97$ (dd, $J=$ 8.9, $1.5 \mathrm{~Hz}, 4 \mathrm{H}), 4.08-3.98(\mathrm{~m}, 4 \mathrm{H}), 3.44$ (q, $J=7.2 \mathrm{~Hz}, 6 \mathrm{H}), 3.33-$ 3.26 (m, 2H), 1.89-1.71 (m, 6H), 1.57-1.49 (m, 3H), 1.49-1.43 $(\mathrm{m}, 2 \mathrm{H}), 1.38(\mathrm{t}, J=7.1 \mathrm{~Hz}, 10 \mathrm{H}), 1.25(\mathrm{~s}, 15 \mathrm{H}), 0.87(\mathrm{t}, J=6.7 \mathrm{~Hz}$, $3 \mathrm{H}) .{ }^{13} \mathrm{C}$ NMR (101 MHz, $\mathrm{CDCl}_{3}$ ) $\delta / \mathrm{ppm} 161.34,161.04,146.96$ $(\mathrm{d}, J=12.8 \mathrm{~Hz}), 124.39,114.81$ (d, $J=7.0 \mathrm{~Hz}), 77.48,77.16$, 76.84, 68.45, 67.98, 57.80, 53.88, 31.99, 30.02-29.18 (m), 29.02, $26.19(\mathrm{~d}, J=19.0 \mathrm{~Hz}), 25.76,22.76,22.28,14.20,8.43$.

\subsection{Mesomorphic studies}

The thermal behaviour and liquid crystalline properties of all the synthesized compounds were studied via polarizing optical 
microscopy (POM) and differential scanning calorimetry (DSC). For polarizing microscopy, a Linkam hot stage and temperature observation under polarized light of an Olympus BX 51 polarizing optical microscope were used. The magnification used to capture the optical texture was $10 \times$ and $200 \mu \mathrm{m}$. DSC thermograms were recorded using a PerkinElmer DSC-7 with heating and cooling rates of $5{ }^{\circ} \mathrm{C} \mathrm{min}^{-1}$.

\subsection{Photoswitching studies}

The UV-vis spectra of the azobenzene-based ionic liquids and their intermediates were recorded using an Ocean Optics HR2000+ UV-vis spectrophotometer setup. The photoisomerization of the azo compounds were recorded in a dark room in the wavelength range of $250 \mathrm{~nm}$ to $800 \mathrm{~nm}$, and chloroform was used as the blank. At fixed concentration of $\sim 1.0 \times$ $10^{-5} \mathrm{~mol} \mathrm{~L}^{-1}$ of solution was prepared in chloroform and irradiated with a UV light source (Omni cure series 2000). The irradiation wavelength was $360 \mathrm{~nm}$ and a heat filter was used to keep heat radiation away from the source. The intensity of the irradiation light was $1 \mathrm{~mW} \mathrm{~cm}^{-2}$, which was measured using a UV513AB UV meter. The absorption spectra of compounds 1030 were recorded before illumination and after illumination. After reaching the photosaturation state, the thermal back relaxation was recorded by keeping the samples in the dark. For trans-cis-trans photoisomerization, the changes in absorption spectra upon UV illumination and thermal back relaxation were investigated with respect to time. For thermal back relaxation, first-order plots were plotted for cis $(Z)$ - trans $(E)$ isomerisation of all the compounds and measured at room temperature at $\sim 27{ }^{\circ} \mathrm{C}$.

\section{Conclusions}

In summary, the photoresponsive behaviour of $N, N$-diethanol6-(4-((4'-alkyloxyphenyl)diazenyl)phenoxy)hexan-1-ammonium iodides, 22-24, $N$-ethyl- $N$-ethanol-6-(4-((4'-alkyloxyphenyl) diazenyl)phenoxy)hexan-1-ammonium iodides, 25-27 and $N, N$-diethyl-6-(4-((4'-alkyloxyphenyl)diazenyl)phenoxy)hexan-1ammonium iodides, 28-30 and their intermediates 10-21 was characterized and their mesomorphic and photoswitching properties investigated. The schlieren texture of the smectic C (tilted) and smectic B phases was observed in case of the highest substituted carbon atom length in the alkoxy chain $(n=12)$ in the side chain of the azo moiety. The natural focal conic texture of the smectic A (non-tilted) phases was observed for all the compounds except the compound without a hydroxyl group in the terminal head group of its azo moieties. In the case of compound 30, after $45 \mathrm{~s}$, the photoequilibrium state was achieved under UV irradiation and its photoisomerization efficiency was greater than 95\%. Its thermal back relaxation time was about $\sim 590 \mathrm{~min}$ in solution at room temperature. The photoisomerization reaction rate was affected by the hydrophobic and hydrophilic head groups, and it also affected the equilibrium isomerization efficiency of the compounds. Thus, the azobenzene at the end of the head group bearing a hydroxyl group influences the thermal back relaxation. As a result, the presence of a hydroxyl group on the ammonium group decreases the thermal back relaxation time. In the case of the solid cell, the thermal back relaxation time achieved was $\sim 400 \mathrm{~min}$. These results suggest that chemical modification of the photoresponsive behaviour of azobenzene derivatives can be useful for the design of molecular switches and optical storage devices.

\section{Conflicts of interest}

There are no conflicts to declare.

\section{Acknowledgements}

This research work was supported by DST-SERB (Department of Science and Technology-Science and Engineering Research Board) Govt of India under ECR grant (File No. ECR/2015/ 000190) and Universiti Sains Malaysia through the RUI research grant (Grant No. 1001/PKIMIA/8011094). We also thank Hima S Reddy for helping us to conduct the photoisomerization experiments.

\section{Notes and references}

1 G. Hegde, G. Shankar, S. M. Gan, A. R. Yuvaraj, S. Mahmood and U. K. Mandal, Liq. Cryst., 2016, 43(11), 1578-1588.

2 M. L. Rahman, M. M. Yusoff and S. Kumar, RSC Adv., 2014, 4(66), 35089-35098.

3 M. L. Rahman, G. Hegde, M. Azazpour, M. M. Yusoff and S. Kumar, J. Fluorine Chem., 2013, 156, 230-235.

4 L. Rahman, S. Kumar, C. Tschierske, G. Israel, D. Ster and G. Hegde, Liq. Cryst., 2009, 36(4), 397-407.

5 M. R. Lutfor, G. Hegde, S. Kumar, C. Tschierske and V. G. Chigrinov, Opt. Mater., 2009, 32(1), 176-183.

6 S. K. Prasad, G. G. Nair and D. S. Rao, Liq. Cryst., 2009, 36(67), 705-716.

7 J. Sun and V. Chigrinov, Mol. Cryst. Liq. Cryst., 2012, 561(1), $1-7$.

8 M. R. Lutfor, M. M. Yusoff, G. Hegde, M. N. Fazli, A. Malek, N. A. Samah and H. T. Srinivasa, Mol. Cryst. Liq. Cryst., 2013, 587, 41-53.

9 A. R. Yuvraj, W. S. Yam, T. N. Chan, Y. P. Goh and G. Hegde, Spectrochim. Acta, Part A, 2015, 135, 1115-1122.

10 Y. Norikane, Y. Hirai and M. Yoshida, Chem. Commun., 2011, 47(6), 1770-1772.

11 A. Ziegler, J. Stumpe, A. Toutianoush and B. Tieke, Colloids Surf., A, 2002, 198, 777-784.

12 A. R. Yuvaraj, G. S. Mei, A. D. Kulkarni, M. Y. Mashitah and G. Hegde, $R S C A d v$., 2014, 4(92), 50811-50818.

13 S. M. Gan, A. R. Yuvaraj, M. R. Lutfor, M. Y. Mashitah and H. Gurumurthy, RSC Adv., 2015, 5(9), 6279-6285.

14 G. Hegde, V. M. Kozenkov, V. G. Chigrinov and H. S. Kwok, Mol. Cryst. Liq. Cryst., 2009, 507(1), 41-50.

15 V. Jayalakshmi, G. Hegde, G. G. Nair and S. K. Prasad, Phys. Chem. Chem. Phys., 2009, 11(30), 6450-6454.

16 G. Hegde, A. R. Yuvaraj, W. Sinn-Yam and M. M. Yusoff, in Macromolecular Symposia, 2015, vol. 353, pp. 240-245. 
17 M. Alaasar, M. Prehm, K. May, A. Eremin and C. Tschierske, Adv. Funct. Mater., 2014, 24(12), 1703-1717.

18 M. Alaasar, M. Prehm, M. Brautzsch and C. Tschierske, J. Mater. Chem. C, 2014, 2(28), 5487-5501.

19 M. M. Naoum, A. A. Fahmi, N. H. Ahmed and G. R. Saad, Liq. Cryst., 2015, 42(9), 1298-1308.

20 M. M. Naoum, A. A. Fahmi, A. H. Abaza and G. R. Saad, Liq. Cryst., 2014, 41(11), 1559-1568.

21 M. Podruczna, A. Hofmańska, I. Niezgoda, D. Pociecha and Z. Galewski, Liq. Cryst., 2014, 41(1), 113-125.

22 Z. Li, H. Wang, M. Chu, P. Guan, Y. Zhao, Y. Zhao and J. Wang, RSC Adv., 2017, 7(71), 44688-44695.

23 R. Hayes, G. G. Warr and R. Atkin, Chem. Rev., 2015, 115, 6357-6426.

24 J. E. S. J. Reid, F. Agapito, C. E. S. Bernardes, F. Martins, A. J. Walker, S. Shimizu and M. E. Minas da Piedade, Phys. Chem. Chem. Phys., 2017, 19, 19928-19936.

25 O. Palumbo, F. Trequattrini, M. A. Navarra, J. B. Brubach, P. Roy and A. Paolone, Phys. Chem. Chem. Phys., 2017, 19, 8322-8329.

26 K. Dong, X. Liu, H. Dong, X. Zhang and S. Zhang, Chem. Rev., 2017, 117, 6636-6695.

27 D. Andrienko, J. Mol. Liq., 2018, 267, 520-541.

28 D. D. Díaz, D. Kühbeck and R. J. Koopmans, Chem. Soc. Rev., 2011, 40(1), 427-448.

29 M. Ikeda, R. Ochi and A. W. I. Hamachi, Chem. Sci., 2010, 1, 491-498.

30 M. A. C. Stuart, W. T. Huck, J. Genzer, M. Müller, C. Ober, M. Stamm and F. Winnik, Nat. Mater., 2010, 9(2), 101.
31 X. Chen, J. Gao, B. Song, M. Smet and X. Zhang, Langmuir, 2009, 26, 104-108.

32 K. Stappert, J. Muthmann, E. T. Spielberg and A. V. Mudring, Cryst. Growth Des., 2015, 15(9), 4701-4712.

33 L. J. Yu, R. G. Peng, Y. Z. Wang and Y. K. Yang, Adv. Mater. Res., 2012, 534, 122-125.

34 H. Tamura, Y. Shinohara and T. Arai, Chem. Lett., 2010, 39, 240-241.

35 S. Zhang, S. Liu, Q. Zhang and Y. Deng, Chem. Commun., 2011, 47, 6641-6643.

36 J. Avó, L. Cunha-Silva, J. Lima and A. Jorge Parola, Org. Lett., 2014, 16, 2582-2585.

37 J. Yang, H. Wang, J. Wang, Y. Zhang and Z. Guo, Chem. Commun., 2014, 50, 14979-14982.

38 S. Shi, T. Yin, X. Tao and W. Shen, RSC Adv., 2015, 5, 7580675809.

39 A. Wu, F. Lu, P. Sun, X. Gao, L. Shi and L. Zheng, Langmuir, 2016, 32, 8163-8170.

40 E. Madiahlagan, B. N. Sunil, Z. Ngaini and G. Hegde, J. Mol. Liq., 2019, 292, 111328.

41 N. Trbojevic, J. C. Haenle, T. Wöhrle, J. Kirres and S. Laschat, Liq. Cryst., 2016, 43(8), 1135-1147.

42 W. J. Goodby, Handbook of Liquid Crystals Set, 1998, pp. 411440.

43 M. L. Rahman, G. Hegde, M. M. Yusoff, M. N. F. A. Malek, H. T. Srinivasa and S. Kumar, New J. Chem., 2013, 37(8), 2460-2467. 